\title{
Nitrogen cycling in the deep sedimentary biosphere: nitrate isotopes in porewaters underlying the oligotrophic North Atlantic
}

\author{
S. D. Wankel ${ }^{1}$, C. Buchwald ${ }^{1}$, W. Ziebis ${ }^{2}$, C. B. Wenk ${ }^{3, a}$, and M. F. Lehmann ${ }^{3}$ \\ ${ }^{1}$ Woods Hole Oceanographic Institution, Department of Marine Chemistry and Geochemistry, 266 Woods Hole Rd., Woods \\ Hole, MA 02543, USA \\ ${ }^{2}$ University of Southern California, Department of Biological Sciences, Allan Hancock Foundation Building, Los Angeles, \\ CA 90089, USA \\ ${ }^{3}$ University of Basel, Department of Environmental Science, Bernoullistrasse 32, Basel, 4056, Switzerland \\ ${ }^{a}$ now at: Weizmann Institute of Science, Department of Earth and Planetary Sciences, Rehovot, 76100, Israel
}

Correspondence to: S. D. Wankel (sdwankel@whoi.edu)

Received: 31 July 2015 - Published in Biogeosciences Discuss.: 21 August 2015

Revised: 11 November 2015 - Accepted: 26 November 2015 - Published: 21 December 2015

\begin{abstract}
Nitrogen (N) is a key component of fundamental biomolecules. Hence, its cycling and availability are central factors governing the extent of ecosystems across the Earth. In the organic-lean sediment porewaters underlying the oligotrophic ocean, where low levels of microbial activity persist despite limited organic matter delivery from overlying water, the extent and modes of nitrogen transformations have not been widely investigated. Here we use the $\mathrm{N}$ and oxygen $(\mathrm{O})$ isotopic composition of porewater nitrate $\left(\mathrm{NO}_{3}^{-}\right)$ from a site in the oligotrophic North Atlantic (Integrated Ocean Drilling Program - IODP) to determine the extent and magnitude of microbial nitrate production (via nitrification) and consumption (via denitrification). We find that $\mathrm{NO}_{3}^{-}$accumulates far above bottom seawater concentrations $(\sim 21 \mu \mathrm{M}$ ) throughout the sediment column (up to $\sim 50 \mu \mathrm{M}$ ) down to the oceanic basement as deep as $90 \mathrm{mb}$ b.f. (below sea floor), reflecting the predominance of aerobic nitrification/remineralization within the deep marine sediments. Large changes in the $\delta^{15} \mathrm{~N}$ and $\delta^{18} \mathrm{O}$ of nitrate, however, reveal variable influence of nitrate respiration across the three sites. We use an inverse porewater diffusion-reaction model, constrained by the $\mathrm{N}$ and $\mathrm{O}$ isotope systematics of nitrification and denitrification and the porewater $\mathrm{NO}_{3}^{-}$isotopic composition, to estimate rates of nitrification and denitrification throughout the sediment column. Results indicate variability of reaction rates across and within the three boreholes that are generally consistent with the differential distribution of dissolved oxygen at this site, though not necessarily with
\end{abstract}

the canonical view of how redox thresholds separate nitrate regeneration from dissimilative consumption spatially. That is, we provide stable isotopic evidence for expanded zones of co-occurring nitrification and denitrification. The isotope biogeochemical modeling also yielded estimates for the $\delta^{15} \mathrm{~N}$ and $\delta^{18} \mathrm{O}$ of newly produced nitrate $\left(\delta^{15} \mathrm{~N}_{\mathrm{NTR}}\right.$ (NTR, referring to nitrification) and $\delta^{18} \mathrm{O}_{\mathrm{NTR}}$ ), as well as the isotope effect for denitrification ( ${ }^{15} \varepsilon_{\mathrm{DNF}}$ ) (DNF, referring to denitrification), parameters with high relevance to global ocean models of $\mathrm{N}$ cycling. Estimated values of $\delta^{15} \mathrm{~N}_{\mathrm{NTR}}$ were generally lower than previously reported $\delta^{15} \mathrm{~N}$ values for sinking particulate organic nitrogen in this region. We suggest that these values may be, in part, related to sedimentary $\mathrm{N}_{2}$ fixation and remineralization of the newly fixed organic N. Values of $\delta^{18} \mathrm{O}_{\mathrm{NTR}}$ generally ranged between -2.8 and $0.0 \%$, consistent with recent estimates based on lab cultures of nitrifying bacteria. Notably, some $\delta^{18} \mathrm{O}_{\mathrm{NTR}}$ values were elevated, suggesting incorporation of ${ }^{18} \mathrm{O}$-enriched dissolved oxygen during nitrification, and possibly indicating a tight coupling of $\mathrm{NH}_{4}^{+}$and $\mathrm{NO}_{2}^{-}$oxidation in this metabolically sluggish environment. Our findings indicate that the production of organic matter by in situ autotrophy (e.g., nitrification, nitrogen fixation) supplies a large fraction of the biomass and organic substrate for heterotrophy in these sediments, supplementing the small organic-matter pool derived from the overlying euphotic zone. This work sheds new light on an active nitrogen cycle operating, despite exceedingly low carbon inputs, in the deep sedimentary biosphere. 


\section{Introduction}

Below the surface ocean, the dark ocean, including environments above and below the seafloor, hosts the largest habitable environment on the planet and is home to a wide range of globally relevant biogeochemical processes (Orcutt et al., 2011). While significant progress has been made in recent years toward characterizing the geological, chemical, and ecological composition of a variety of subsurface environments (Orcutt et al., 2011; Edwards et al., 2011, 2012b), the potential for impact of these systems on global biogeochemical cycles remains poorly understood. Most of our knowledge about subseafloor microbial activity stems from research focusing on productive continental margins, where relatively high fluxes of organic matter from surface primary productivity support a large heterotrophic and mostly anaerobic microbial community (e.g., Blair and Aller, 2012). By comparison, vast areas of the seafloor, in particular those underlying ocean gyres, characterized by low primary productivity and low organic-matter flux to the sea floor, have received far less attention (D'Hondt et al., 2009; Mason et al., 2010; Fischer et al., 2009). In contrast to well-studied ocean margin sediments, oxygen $\left(\mathrm{O}_{2}\right)$ and nitrate $\left(\mathrm{NO}_{3}^{-}\right)$, two powerful oxidants of organic carbon, penetrate deeply into the sediment underlying oligotrophic ocean waters (D'Hondt et al., 2009, 2015; Murray and Grundmanis, 1980; Rutgers van der Loeff et al., 1990; Sachs et al., 2009; Røy et al., 2012; Fischer et al., 2009). Furthermore, in the sediments overlying relatively young and permeably ocean crust, $\mathrm{O}_{2}$ and $\mathrm{NO}_{3}^{-}$are also supplied via upward diffusion from oxic and nitrate-replete fluids flowing through basaltic basement as has been shown for the North Pond site, which is located on the western flank of the Mid-Atlantic Ridge (Orcutt et al., 2013; Ziebis et al., 2012). At North Pond, where the sediment cover is thin $(<\sim 25 \mathrm{~m}), \mathrm{O}_{2}$ penetrates the entire sediment column; where sediment thickness is elevated, conditions become anoxic at mid-depths. Aerobic heterotrophic respiration likely dominates organic carbon oxidation in the upper sediment column. However, as organic carbon becomes limiting at greater depths, autotrophic processes (e.g., nitrification) are likely to gain relative importance. Further, there is evidence that the upward supply of oxidants from the basaltic basement supports increased microbial activity (Picard and Ferdelman, 2011). However, a fundamental understanding of the relative importance of specific metabolic activities that drive and sustain subsurface communities is lacking. Because central ocean gyres cover roughly half of the global seafloor, understanding the nature of the biosphere hosted within these sediments may provide important insights into its role in global marine nitrogen and carbon cycling. Here we focus specifically on elucidating subsurface nitrogen cycling and its role in supporting heterotrophic and autotrophic processes in oligotrophic deep-ocean sediments underlying the North Atlantic Gyre, at North Pond $\left(22^{\circ} 45^{\prime} \mathrm{N}\right.$, $46^{\circ} 05^{\prime} \mathrm{W}$ ).
Integrated Ocean Drilling Program (IODP) Expedition 336 (Mid-Atlantic Ridge Microbiology, 16 September-16 November 2011) aimed to directly address the nature of microbial communities in both ocean crust and sediments at North Pond, a characteristic sediment-filled $70 \mathrm{~km}^{2}$ depression surrounded by high relief topography common to the western flank of the Mid-Atlantic Ridge (Becker et al., 2001; Langseth et al., 1992). While a majority of seafloor subsurface biosphere research has focused on aspects of sedimentary carbon, sulfur, and iron cycles, the potential role of $\mathrm{N}$ in supporting subsurface microbial activity has been largely unexplored. Despite exceedingly oligotrophic conditions, life persists and evidence for active heterotrophic and autotrophic microbial communities in North Pond sediments is mounting (Ziebis et al., 2012; Picard and Ferdelman, 2011; Orcutt et al., 2013).

Nitrogen plays a central role as a limiting nutrient in many regions of the sunlit surface ocean (Rabalais, 2002), as nearly $90 \%$ of the biologically available fixed $\mathrm{N}$ in the ocean resides below the euphotic zone in the deep ocean $\mathrm{NO}_{3}^{-}$reservoir (Gruber, 2008). Globally, sediments (especially continental shelves) are considered a net sink of fixed nitrogen through reductive anaerobic processes including denitrification and anaerobic ammonium oxidation (Christensen et al., 1987; Devol, 1991; Prokopenko et al., 2013). For example, coupled nitrification (the chemolithotrophic oxidation of $\mathrm{NH}_{4}^{+}$ to $\mathrm{NO}_{3}^{-}$) and denitrification (the typically heterotrophic reduction of $\mathrm{NO}_{3}^{-}$to $\mathrm{N}_{2}$ ) have been shown to be important in $\mathrm{N}$ budgets in sediments of continental shelves, ocean margins, and estuaries (Risgaard-Petersen, 2003; Granger et al., 2011; Lehmann et al., 2004, 2005; Wankel et al., 2009). There is abundant evidence demonstrating the importance of both oxidative and reductive $\mathrm{N}$ cycling processes (and their tight coupling) operating in sediment environments. In contrast to sediments on continental shelves, however, data from sediments underlying large swaths of the oligotrophic ocean suggest an entirely different framework. For example, $\mathrm{NO}_{3}^{-}$ concentration data from North Pond demonstrate the accumulation of $\mathrm{NO}_{3}^{-}$with depth (Ziebis et al., 2012) implicating the role of in situ production supported by the autotrophic oxidation of ammonium and nitrite (e.g., nitrification). To what degree this $\mathrm{NO}_{3}^{-}$pool supports other subsurface microbial communities as an electron acceptor source, however, remains unclear. In addition, the supply of dissolved substrates $\left(\mathrm{O}_{2}, \mathrm{NO}_{3}^{-}, \mathrm{DOC}\right)$ from the underlying crustal aquifer may play a primary role in supporting these deep sediment communities. At a global scale, this geochemical exchange among crust, ocean, and sediments across vast reaches of the seafloor, and its link to subsurface microbial activity, may well be important for global biogeochemical cycles.

Dual isotopes of $\mathrm{NO}_{3}^{-}$represent a powerful tool for disentangling the combined activities of multiple $\mathrm{N}$ cycling processes (Casciotti et al., 2008; Lehmann et al., 2005; Sigman et al., 2005; Wankel et al., 2007; Marconi et al., 2015; 
Fawcett et al., 2015). Nitrate-removal processes (whether assimilatory or dissimilatory) have been shown to impart linearly coupled increases in both $\mathrm{N}$ and $\mathrm{O}$ isotope ratios of the remaining $\mathrm{NO}_{3}^{-}$pool (Karsh et al., 2012; Kritee et al., 2012; Granger et al., 2004, 2008). In contrast, however, nitrification, the two-step oxidation of $\mathrm{NH}_{4}^{+}$to $\mathrm{NO}_{2}^{-}$followed by $\mathrm{NO}_{2}^{-}$oxidation to $\mathrm{NO}_{3}^{-}$, represents a decoupling of the $\mathrm{N}$ and $\mathrm{O}$ isotope systems in the resulting nitrate (Casciotti and McIlvin, 2007; Buchwald and Casciotti, 2013; Wankel et al., 2007). Whereas the $\mathrm{N}$ atoms derive from the $\mathrm{NH}_{4}^{+}$(which can be assumed to originate from the sedimentary organic nitrogen pool), the oxygen atoms derive, to varying degrees, from both water and dissolved $\mathrm{O}_{2}$ (Buchwald and Casciotti, 2010; Buchwald et al., 2012; Casciotti et al., 2010). Thus, by combining isotope mass balances of both $\mathrm{N}$ and $\mathrm{O}$ in the $\mathrm{NO}_{3}^{-}$system, along with our understanding of organismlevel constraints on the isotope systematics of these transformations, we can deduce the relative roles of multiple $\mathrm{N}$ cycling processes (e.g., Wankel et al., 2009; Lehmann et al. 2004; Bourbonnais et al., 2009). Here we use the dual isotopic composition of nitrate ( $\mathrm{N}$ and $\mathrm{O}$ isotopes) as a record of microbial processes occurring in the low-carbon sediments of North Pond underlying the oligotrophic North Atlantic gyre. By combining the $\mathrm{N}$ and $\mathrm{O}$ isotope mass balance with an inverse reaction-diffusion model approach, we use these data to estimate rates of nitrification and denitrification, and to provide new constraints on some isotope parameters for these processes.

\section{Material and methods}

\subsection{Sediment and porewater collection}

Sediment cores were collected at three sites in the North Pond Basin (Fig. 1) as part of the IODP Leg 336 expedition and have been described extensively elsewhere (Expedition336-Scientists, 2012). Four boreholes were drilled (U1382B, U1383D, U1383E, and U1384A, referred to hereafter as 2B, $3 \mathrm{D}, 3 \mathrm{E}$, and $4 \mathrm{~A})$. Sites $3 \mathrm{D}$ and $3 \mathrm{E}$ were next to each other and as drilling logs indicated that the core from $3 \mathrm{E}$ showed excessive signs of disturbance upon retrieval and potential contamination by seawater, it was excluded from our study. Sediment cores were retrieved using the advanced piston corer, which penetrated the seafloor sediments until contact with basement, followed by extended core barrel coring of the upper section of basement rock. Site $2 \mathrm{~B}(\sim 90 \mathrm{~m}$ sediment thickness, depth to basement) is located in the deeper part of the pond, approximately $25 \mathrm{~m}$ away from DSDP (Deep Sea Drilling Project) legacy hole 395A, which was instrumented as a CORK (Circulation Obviation Retrofit Kit) observatory (Davis et al., 1992). Site 3D ( $42 \mathrm{~m}$ sediment thickness, depth to basement) lies in the northeastern region towards the edge of North Pond ( $\sim 5.9 \mathrm{~km}$ away from U1382A), whereas site $4 \mathrm{~A}(\sim 95 \mathrm{~m}$ sediment thickness, depth to base-

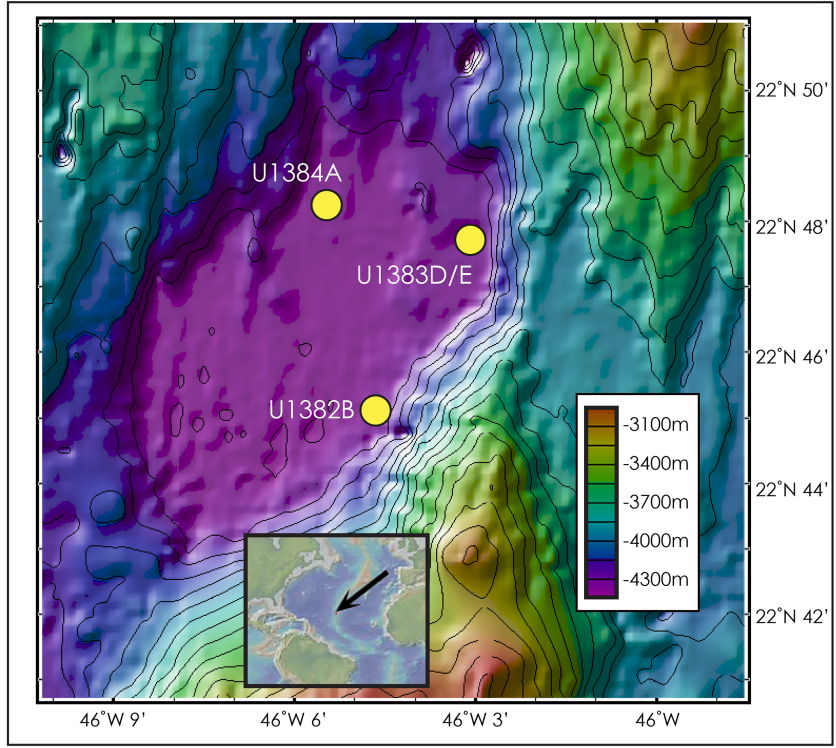

Figure 1. Map of North Pond study site (created using the default Multi-Resolution Topography Synthesis base map in GeoMapApp ver. 3.5.1). Color scale reflects water depth in meters with contour intervals of $100 \mathrm{~m}$.

ment) is located on the northwest side in a deeper part of the basin, approximately 3.9 and $6.2 \mathrm{~km}$ in distance from U1383 and U1382, respectively (Fig. 1). A total of 2 decades of temperature and flow records revealed vigorous subsurface flow (Becker et al., 1984; Gable et al., 1992), with geothermal surveys indicating that recharge is from the southeastern side of the basin (near 2B and 3D) flowing to the northwest (towards 4A) (Fig. 1). All sediments were comprised of light-brown to brown nannofossil ooze with intercalations of foraminiferal sand. In the lowest few meters close to the sediment/basement contact, sediments exhibited a darker brown color and sometimes rust-colored clay-rich zones (Edwards et al., 2012a; Expedition-336-Scientists, 2012).

Porewater samples for concentration and stable isotope analyses were collected either directly from cores on the shipboard catwalk immediately after core retrieval (and stored at $-80^{\circ} \mathrm{C}$ until analysis), from whole core rounds ( $\sim 10 \mathrm{~cm}$ core sections) that had been preserved at $-80^{\circ} \mathrm{C}$ for $\sim 1$ year until thawing and porewater extraction, or from subsampled sediments collected shipboard and stored at $-20^{\circ} \mathrm{C}$ for $\sim 9$ months. Porewaters from whole core rounds ( $\sim 40 \mathrm{~mL})$ and subsampled sediments $(\sim 3 \mathrm{~mL})$, were extracted using Rhizon samplers $(0.2 \mu \mathrm{m})$ (Seeberg-Elverfeldt et al., 2005) and stored frozen $\left(-20^{\circ} \mathrm{C}\right)$ until analysis. 


\subsection{Concentration measurements}

Concentrations of $\mathrm{NO}_{x}$ (i.e., $\mathrm{NO}_{3}^{-}$plus $\mathrm{NO}_{2}^{-}$) from shipboard-extracted porewaters were measured via ion chromatography $\sim 3$ months after collection, while concentrations from home-laboratory-extracted porewaters were measured by chemiluminescence after reduction in a hot acidic vanadyl sulfate solution on a $\mathrm{NO}_{x}$ analyzer (Braman and Hendrix, 1989) (detection limit $<0.5 \mu \mathrm{M}$ ). Concentrations of $\mathrm{NO}_{2}^{-}$were quantified by using the Griess-Ilosvay method followed by measuring absorption at $540 \mathrm{~nm}$ (Grasshoff et al., 1999) or by chemiluminescence in a sodium iodide solution on a $\mathrm{NO}_{x}$ analyzer (Garside, 1982; Cox, 1980). $\mathrm{NO}_{3}^{-}$was quantified by the difference between $\mathrm{NO}_{x}$ and $\mathrm{NO}_{2}^{-}$(Grasshoff et al., 1999). Ammonium concentrations were measured using the orthophthaldialdehyde fluorescence method with an empirically determined sensitivity limit of $\sim 0.5 \mu \mathrm{M}$ for porewaters (Holmes et al., 1999).

\subsection{Nitrate stable isotope composition}

Nitrate $\mathrm{N}$ and $\mathrm{O}$ isotopic composition were measured using the denitrifier method (Casciotti et al., 2002; Sigman et al., 2001), in which sample $\mathrm{NO}_{3}^{-}$is quantitatively converted to $\mathrm{N}_{2} \mathrm{O}$ using a lab-grown denitrifying bacterium before being extracted and purified on a purge-and-trap system similar to that previously described (McIlvin and Casciotti, $2010)$. Where detected $\left(\mathrm{O}_{2}\right.$-depleted zones of $\left.2 \mathrm{~B}\right), \mathrm{NO}_{2}^{-}$was removed by sulfamic acid addition (Granger and Sigman, 2009) prior to isotopic analysis of the $\mathrm{NO}_{3}^{-}$. Isotopic analysis of shipboard-extracted samples (16) were conducted at the University of Basel using a Delta V Advantage (Thermo, Inc.), while all other samples (29) were measured on an IsoPrime100 (Elementar, Inc.). Corrections for drift, size and fractionation of $\mathrm{O}$ isotopes during bacterial conversion were carried out as previously described using $\mathrm{NO}_{3}^{-}$standards USGS 32, USGS 34, and USGS 35 (Casciotti et al., 2002; McIlvin and Casciotti, 2011), with a typical reproducibility of 0.2 and $0.4 \%$ for $\delta^{15} \mathrm{~N}$ and $\delta^{18} \mathrm{O}$, respectively.

\section{Results}

\subsection{Previous measurements of dissolved oxygen and organic matter content at North Pond}

Oxygen penetration depths, which have been discussed previously (Orcutt et al., 2013), vary distinctly among the three sites at North Pond indicating much greater respiratory consumption in $2 \mathrm{~B}$ than in the profiles of other two sites, 3D and 4A (Fig. 2). In 2B, dissolved oxygen levels are drawn down to near detection by a depth of about $10 \mathrm{~m}$ b.s.f. (below sea floor) (although low levels of dissolved $\mathrm{O}_{2}$ seem to persist as deep as $30 \mathrm{~m}$ b.s.f.). In contrast, at site $3 \mathrm{D}$, dissolved $\mathrm{O}_{2}$ levels are drawn down close to the detection limit $(\sim 5 \mu \mathrm{M})$ for an interval of only $\sim 3 \mathrm{~m}$ between a depth of $\sim 30$ and $\sim 33 \mathrm{~m}$ b.s.f. and in $4 \mathrm{~A}$, zero-level $\mathrm{O}_{2}$ concentrations were observed over the interval between 32 and $54 \mathrm{~m}$ b.s.f. At North Pond, $\mathrm{O}_{2}$ (and $\mathrm{NO}_{3}^{-}$) is also supplied via diffusion from the underlying basaltic crustal aquifer (Fig. 2) (Orcutt et al., 2013; Ziebis et al., 2012). Although not measured during this work, sediment organic carbon and nitrogen content was measured on several of the piston cores collected during the site survey, averaging 0.15 and $0.02 \%$, respectively (Ziebis et al., 2012). Although quantification of such low organic-N and organic-C levels is challenging and is afflicted with relatively large uncertainties, no discernible organic matter elemental differences among the sites were noted (Ziebis et al., 2012). Similarly, no differences in organic phosphorus content were noted among the three sites (Defforey and Paytan, 2015).

\section{2 $\mathrm{NO}_{3}^{-}$and $\mathrm{NO}_{2}^{-}$concentration profiles}

Bottom seawater $\mathrm{NO}_{3}^{-}$concentration at North Pond is approximately $21.6 \mu \mathrm{M}$ (Ziebis et al., 2012). At all depths in all three profiles, porewater $\mathrm{NO}_{3}^{-}$concentrations exceeded bottom water $\mathrm{NO}_{3}^{-}$concentrations, reflecting the production of $\mathrm{NO}_{3}^{-}$by nitrification and the net flux of $\mathrm{NO}_{3}^{-}$to the overlying water from this site of $\sim 4.6 \mu$ moles $\mathrm{m}^{-2} \mathrm{~d}^{-1}$ (Ziebis et al., 2012), consistent with other studies of $\mathrm{NO}_{3}^{-}$fluxes in pelagic deep-sea sediments (Berelson et al., 1990; Goloway and Bender, 1982; Hammond et al., 1996; Jahnke et al., 1982; Grundmanis and Murray, 1982). More precisely, below the sediment-water interface, $\mathrm{NO}_{3}^{-}$concentrations increased significantly with depth (Fig. 2), before decreasing again with proximity to the basement/sediment contact. Midprofile $\mathrm{NO}_{3}^{-}$concentration maxima reached 38.2, 42.2, and $49.1 \mu \mathrm{M}$ at depths of $19.1,23.0$, and $56.3 \mathrm{~m}$ b.s.f. in the cores from sites $2 \mathrm{~B}, 3 \mathrm{D}$, and $4 \mathrm{~A}$, respectively - depths that generally coincided with $\mathrm{O}_{2}$ concentrations below $10 \mu \mathrm{M}$. Nitrite was below detection at sties 3D and 4A and was only detected at anoxic depths in site 2B (Fig. 2), where concentrations of up to 6.0 and $6.6 \mu \mathrm{M}$ were observed at depths of 36 and $59 \mathrm{~m}$, respectively.

\section{3 $\mathrm{NO}_{3}^{-} \mathrm{N}$ and $\mathrm{O}$ isotopic composition}

Down-core changes in $\delta^{15} \mathrm{~N}$ and $\delta^{18} \mathrm{O}$ varied markedly among the three cores (Fig. 2). The most prominent changes in both $\delta^{15} \mathrm{~N}$ and $\delta^{18} \mathrm{O}$ were observed at site $2 \mathrm{~B}$ (which had the most extensive $\mathrm{O}_{2}$-depleted zone), in which $\delta^{15} \mathrm{~N}$ increased with depth from a value of $+5.4 \%$ (bottom seawater) to a maximum of $+23.3 \%$ at a depth of $59.2 \mathrm{~m}$ b.s.f. and $\delta^{18} \mathrm{O}$ increased from a bottom seawater value of $+1.8 \%$ o to a maximum of $+23.8 \%$ at a much shallower depth of $32.1 \mathrm{mb}$ b.s. Isotopic maxima generally coincided with depths of lowest $\mathrm{O}_{2}$ concentrations, except in 3D, where the maximum was observed at slightly greater depth than the $\mathrm{O}_{2}$ minimum (Fig. 2). Substantial $\mathrm{N}$ and $\mathrm{O}$ isotopic shifts were also observed at site 3D, in which increases above bot- 


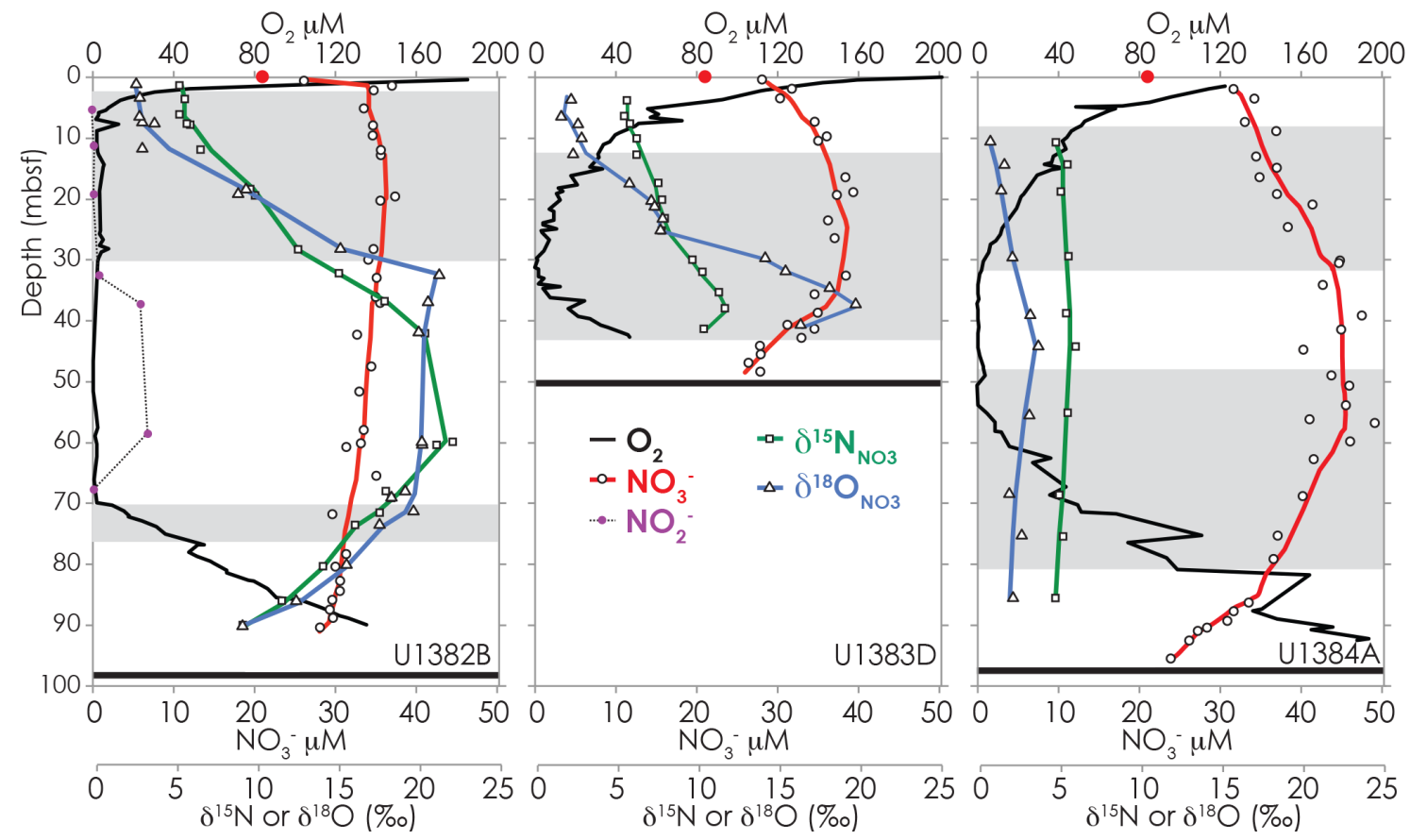

Figure 2. Depth profiles from IODP sites U1382B, U1383D, and U1384A at North Pond of porewater concentrations of $\mathrm{O}_{2}$ (from Orcutt et al., 2013) and $\mathrm{NO}_{3}^{-}$as well as the $\mathrm{N}$ and $\mathrm{O}$ isotopic composition of $\mathrm{NO}_{3}^{-}\left(\delta^{15} \mathrm{~N}_{\mathrm{NO}_{3}}\right.$ and $\left.\delta^{18} \mathrm{O}_{\mathrm{NO}_{3}}^{-}\right)$. The red circle at the top of the profiles denotes the bottom seawater $\mathrm{NO}_{3}^{-}$concentration of $21.6 \mu \mathrm{M}$ (Ziebis et al., 2012). Horizontal black lines indicate depth of contact with ocean crust. Gray boxes indicate "transitional" zones in which a reaction-diffusion model is used to calculate co-occurring nitrification and denitrification (see text for details). Strong increases in $\delta^{15} \mathrm{~N}$ and $\delta^{18} \mathrm{O}$ in $\mathrm{U} 1382 \mathrm{~B}$ coincide with depths having the lowest $\mathrm{O}_{2}$ concentration and are indicative of the influence of denitrification. While the $\mathrm{NO}_{3}^{-}$concentrations profiles of U1383D and U1384A appear similar, stark differences in the nitrate dual isotopic composition reflect the generally low level of microbial activity in U1384A.

tom water $\mathrm{NO}_{3}^{-}$values to $\delta^{15} \mathrm{~N}$ of $+11.8 \%$ and a $\delta^{18} \mathrm{O}$ of $+21.7 \%$ were observed, with both maxima occurring at a depth of $37 \mathrm{~m}$ b.s.f. In contrast, site $4 \mathrm{~A}$ exhibited only very modest changes relative to bottom seawater, with a maximum $\delta^{15} \mathrm{~N}$ value of $+7.0 \%$ at a depth of $38.8 \mathrm{~m}$ b.s.f. and a maximum $\delta^{18} \mathrm{O}$ value of $+6.3 \%$ at a depth of $44.1 \mathrm{~m}$ b.s.f. Strong correlations were also observed between $\delta^{15} \mathrm{~N}_{\mathrm{NO}_{3}}$ and $\delta^{18} \mathrm{O}_{\mathrm{NO}_{3}}$ (Fig. 3), with $\delta^{18} \mathrm{O}_{\mathrm{NO}_{3}}$ values always increasing more than the corresponding $\delta^{15} \mathrm{~N}_{\mathrm{NO}_{3}}^{-}$. The relationship between $\delta^{18} \mathrm{O}_{\mathrm{NO}_{3}}$ and $\delta^{15} \mathrm{~N}_{\mathrm{NO}_{3}}$ exhibited a slope of 1.8 for the upper portion of the $2 \mathrm{~B}$ profile, 3.0 for the $3 \mathrm{D}$ profile and 2.4 for the $4 \mathrm{~A}$ profile - consistently exceeding the $1: 1$ relationship expected from $\mathrm{NO}_{3}^{-}$consumption alone. In $2 \mathrm{~B}$, sampling points near the most $\mathrm{O}_{2}$-depleted depths and the lower portion of the profile fell closer to the expected 1:1 line for $\mathrm{NO}_{3}^{-}$consumption by denitrification (Fig. 3).

\section{Discussion}

The distribution of porewater nitrate in deep-sea sediments is controlled by the combined influence of diffusion as well as several biologically catalyzed diagenetic processes including nitrification (ammonia and nitrite oxidation to nitrate) and denitrification (loss of $\mathrm{N}$ via nitrate reduction to gaseous products, $\mathrm{NO}, \mathrm{N}_{2} \mathrm{O}$ or $\mathrm{N}_{2}$ ). Here we use the concentration and dual $\mathrm{N}$ and $\mathrm{O}$ stable isotope composition of porewater $\mathrm{NO}_{3}^{-}$to gain insight into the magnitude and distribution of $\mathrm{N}$ transformation processes. In comparison to models that predict the rates of these processes based solely on concentration profiles of $\mathrm{NO}_{3}^{-}$and $\mathrm{O}_{2}$, for example, our approach estimates rates using the added constraints provided by recent studies of $\mathrm{N}$ and $\mathrm{O}$ isotope systematics of nitrification and denitrification (Granger et al., 2008; Buchwald and Casciotti, 2010; Casciotti et al., 2010; Buchwald et al., 2012). In particular, while there are strong and related $\mathrm{N}$ and $\mathrm{O}$ isotope effects during denitrification (Granger et al., 2008), the isotopic transformations of $\mathrm{N}$ and $\mathrm{O}$ are decoupled due to differently sourced $\mathrm{N}$ and $\mathrm{O}$ atoms during nitrate production (Buchwald and Casciotti, 2010; Casciotti et al., 2010; Buchwald et al., 2012). Thus, changes in $\mathrm{N}$ and $\mathrm{O}$ isotopic composition between intervals of any one depth are the combined result of both diffusion of $\mathrm{NO}_{3}^{-}$to/from overlying (and underlying) seawater, together with microbially mediated production and/or consumption of $\mathrm{NO}_{3}^{-}$within porewaters. Under low oxygen, $\mathrm{NO}_{3}^{-}$respiration by denitrification leads to a well-characterized increase in both $\delta^{15} \mathrm{~N}$ and $\delta^{18} \mathrm{O}$ in conjunction with decreasing $\mathrm{NO}_{3}^{-}$concentrations. In contrast, 


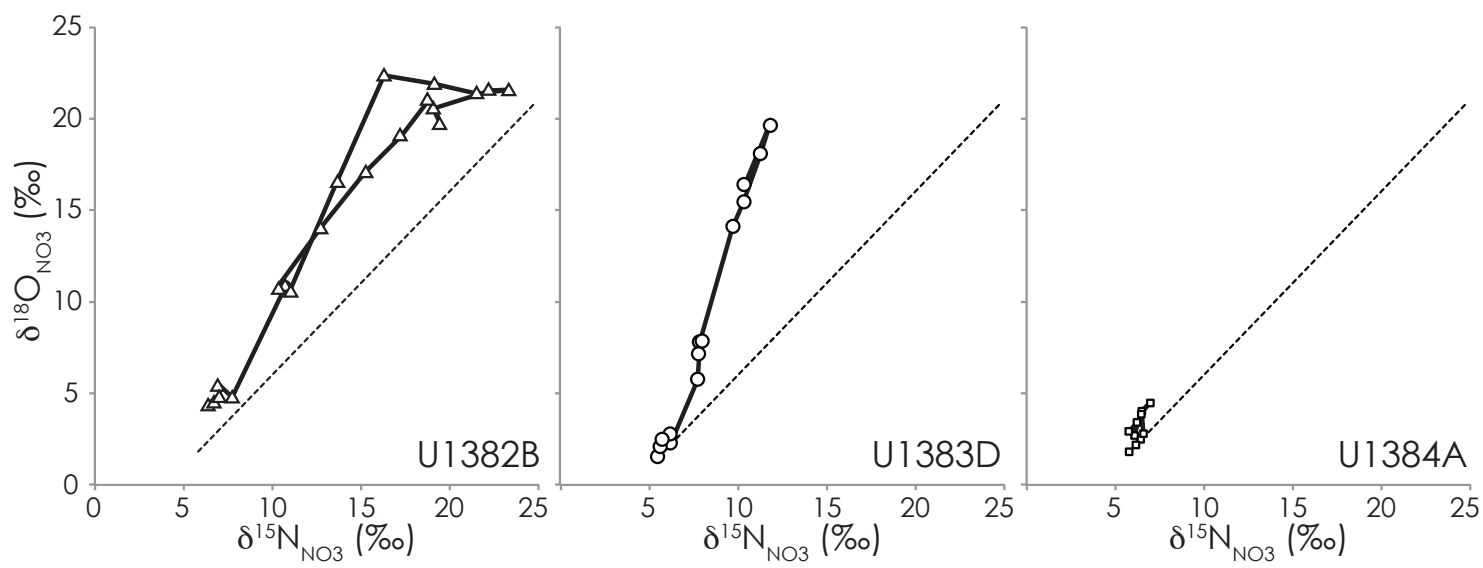

Figure 3. Dual isotope plot illustrating the relationship between $\delta^{15} \mathrm{~N}_{\mathrm{NO}_{3}}$ and $\delta^{18} \mathrm{O}_{\mathrm{NO}_{3}}$ in North Pond porewaters. The diagonal line, rooted at a value for bottom seawater $\left(\delta^{15} \mathrm{~N}\right.$ of $+5.5 \%$ and $\delta^{18} \mathrm{O}$ of $+1.8 \%$ ), depicts a $1: 1$ slope representative of the expected change in $\delta^{15} \mathrm{~N}$ and $\delta^{18} \mathrm{O}$ by the process of denitrification alone. Trends falling well above this $1: 1$ line, together with the concentration profiles reflect the combined role of nitrification in these porewaters.

nitrification produces $\mathrm{NO}_{3}^{-}$with a $\delta^{15} \mathrm{~N}$ equal to the starting $\mathrm{NH}_{4}^{+}$(when accumulation of $\mathrm{NH}_{4}^{+}$and $\mathrm{NO}_{2}^{-}$is negligible), while the $\delta^{18} \mathrm{O}$ of the newly produced $\mathrm{NO}_{3}^{-}$is set by the $\delta^{18} \mathrm{O}$ of ambient $\mathrm{H}_{2} \mathrm{O}$ and $\mathrm{O}_{2}$, as well as kinetic and equilibrium isotope effects associated with the stepwise oxidation of $\mathrm{NH}_{4}^{+}$to $\mathrm{NO}_{3}^{-}$. While elevated $\mathrm{NO}_{3}^{-}$concentrations indicate nitrification, extensive zones of low $\mathrm{O}_{2}$ (and $\mathrm{NO}_{3}^{-}$replete) porewaters also suggest a high potential for denitrification, which can be verified using nitrate dual isotope measurements. In this way, our modeling approach provides an assessment of the distribution of these $\mathrm{N}$ transformations, as well as some additional insights on the nature of $\mathrm{N}$ and $\mathrm{O}$ source atoms to $\mathrm{NO}_{3}^{-}$in these energy-lean systems. Specifically, we show below that the profiles of $\delta^{15} \mathrm{~N}_{\mathrm{NO}_{3}}$ and $\delta^{18} \mathrm{O}_{\mathrm{NO}_{3}}$ can be explained by variations in the magnitude of nitrification and denitrification occurring throughout the sediment column, including substantial zones of overlap of these aerobic/anaerobic processes. Finally, we use our model to predict the $\delta^{18} \mathrm{O}$ and $\delta^{15} \mathrm{~N}$ stemming from nitrate production by nitrification, offering insights into both the nature of processes setting the $\mathrm{O}$ isotopic composition of oceanic $\mathrm{NO}_{3}^{-}$, as well as the sources of $\mathrm{N}$ and/or the isotopic partitioning of available $\mathrm{N}$ sources in global ocean sediments.

\subsection{Diffusion-reaction model}

The diffusion-reaction inverse modeling approach used here is conceptually similar to other early diagenetic models that simulate porewater profiles of dissolved species through a sediment column harboring both oxic and anoxic organic matter remineralization (Christensen and Rowe, 1984; Goloway and Bender, 1982; Jahnke et al., 1982). It is an inverse modeling approach adapted to distinguish between heavy and light nitrate isotopologues (e.g., Lehmann et al.,
2007). Specifically, we use the model to estimate rates of nitrification and denitrification required to fit the concentration profiles of each isotopologue, ${ }^{14} \mathrm{~N}^{16} \mathrm{O}_{3}^{-},{ }^{15} \mathrm{~N}^{16} \mathrm{O}_{3}^{-}$, and ${ }^{14} \mathrm{~N}^{18} \mathrm{O}^{16} \mathrm{O}_{2}^{-}$(and, thus, $\delta^{15} \mathrm{~N}_{\mathrm{NO}_{3}}$ and $\delta^{18} \mathrm{O}_{\mathrm{NO}_{3}}$ values) under the assumption of steady-state diffusion and microbial production (by nitrification) and/or consumption (by denitrification). Rates of nitrification and denitrification in each porewater sampling interval (e.g., defined as the distance between the lower and upper midpoints between sampling depths) were estimated numerically by least-squares fitting of the system of equations describing the distribution of each isotopologue (using a genetic algorithm included in the Solver package of Microsoft Excel 2011). This approach involves determination of a non-unique solution using numerical iteration and optimization, and is repeatedly iterated to evaluate robustness of model fits. Certain parameters are allowed to be optimizable by the model, including both the magnitude of, and connection between, the $\mathrm{N}$ and $\mathrm{O}$ isotope effects for denitrification $\left({ }^{15} \varepsilon_{\mathrm{DNF}}\right.$ and ${ }^{18} \varepsilon_{\mathrm{DNF}}:{ }^{15} \varepsilon_{\mathrm{DNF}}$, respectively), as well as the $\mathrm{N}$ and $\mathrm{O}$ isotopic composition of new $\mathrm{NO}_{3}^{-}$produced by nitrification $\left(\delta^{15} \mathrm{~N}_{\mathrm{NTR}}\right.$ and $\delta^{18} \mathrm{O}_{\mathrm{NTR}}$, respectively). Uncertainty in model estimates is expressed as the standard error of 10 model-run estimates (Table 1). Conditions at the uppermost part of the sediment column were constrained by measured concentrations and isotope ratios in bottom seawater. Measured concentrations of the $\mathrm{NO}_{3}^{-}$ isotopologues within each interval, together with the diffusive fluxes defined by the concentration gradients between the over/underlying intervals, were used for model fitting by least-squares optimization of microbial rates of nitrification and/or denitrification.

As measurable $\mathrm{NH}_{4}^{+}$was not observed at any depths, it is not included in the model. $\mathrm{NO}_{3}^{-}$is the only dissolved $\mathrm{N}$ species included in the model and we assume that all 


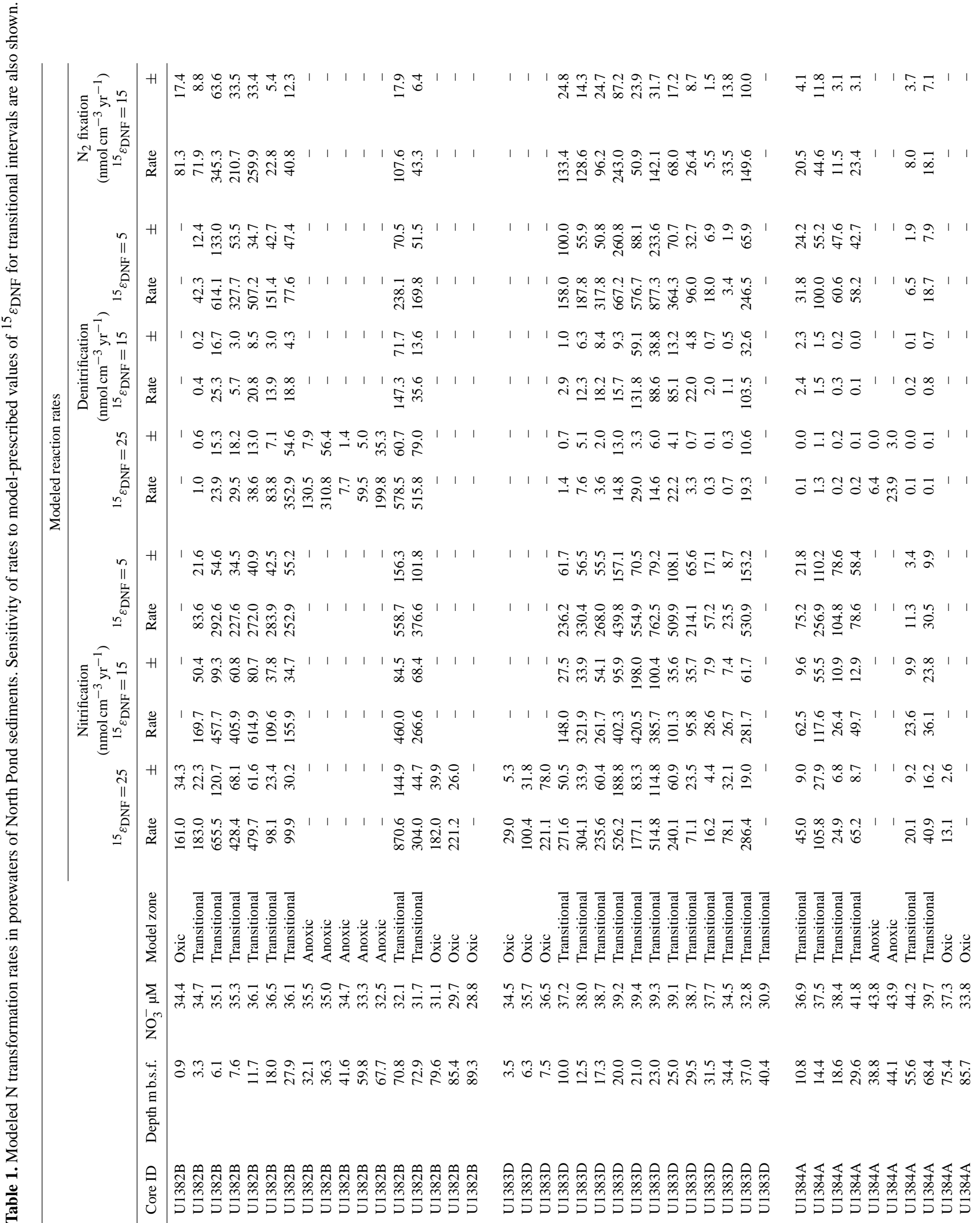


$\mathrm{NH}_{4}^{+}$generated by remineralization is completely oxidized to $\mathrm{NO}_{3}^{-}$(see below). To minimize complexity, other diagenetic reactions that may be important in many sedimentary environments, including anaerobic $\mathrm{NH}_{4}^{+}$oxidation, removal of $\mathrm{N}$ species through interactions with $\mathrm{Fe}$ or $\mathrm{Mn}$ and the adsorption and retention of $\mathrm{NH}_{4}^{+}$by clay minerals are not specifically addressed. We also neglect effects of compaction as well as potential changes in organic matter reactivity with depth. No difference in the diffusivity among $\mathrm{NO}_{3}^{-}$isotopologues was included, since these differences are considered to be very small (Clark and Fritz, 1997).

Resolving the vertical dimension only, the mass balance differential equations are as follows:

$$
\begin{aligned}
& \frac{\partial C_{14}}{\partial t}=\frac{\partial}{\partial z}\left(D_{\mathrm{NO}_{3}} \frac{\partial C_{\mathrm{NO}_{3}}}{\partial z}\right)-\mathrm{DNF}_{14} \mathrm{~N}+\mathrm{NTR}_{14} \mathrm{~N} \\
& \frac{\partial C_{15}}{\partial t}=\frac{\partial}{\partial z}\left(D_{\mathrm{NO}_{3}} \frac{\partial C_{15}}{\partial z}\right)-\mathrm{NNF}_{15} \mathrm{~N}+\mathrm{NTR}_{15} \mathrm{~N} \\
& \frac{\partial C_{16}}{\frac{\mathrm{NO}_{3}}{\partial t}}=\frac{\partial}{\partial z}\left(D_{\mathrm{NO}_{3}} \frac{\partial C_{16}}{\partial z}\right)-\mathrm{NNF}_{16} \mathrm{O}+\mathrm{NTR}_{16} \mathrm{O} \\
& \frac{\partial C_{18}}{\partial \mathrm{NO}_{3}} \\
& \frac{\mathrm{NO}_{3}}{\partial t}=\frac{\partial}{\partial z}\left(D_{\mathrm{NO}_{3}} \frac{\partial C_{18}}{\partial z}\right)-\mathrm{NNF}_{18} \mathrm{O}+\mathrm{NTR}_{18} \mathrm{O}
\end{aligned}
$$

such that for denitrification (DNF):

$$
\begin{aligned}
\mathrm{DNF}_{14} \mathrm{~N}= & C_{{ }_{14} \mathrm{NO}_{3}} \cdot k_{\mathrm{DNF}}, \\
\mathrm{DNF}_{15 \mathrm{~N}}= & C_{1{ }^{15} \mathrm{NO}_{3}} \cdot k_{\mathrm{DNF}} / \alpha_{\mathrm{DNF}}, \\
\mathrm{DNF}_{16} \mathrm{O}= & C_{{ }^{16} \mathrm{NO}_{3}} \cdot k_{\mathrm{DNF}}, \\
\mathrm{DNF}_{18} \mathrm{O}= & C_{{ }_{18} \mathrm{NO}_{3}} \cdot k_{\mathrm{DNF}} /\left[1+\left(\left(\alpha_{\mathrm{DNF}}-1\right)\right.\right. \\
& \left.\left.\cdot\left({ }^{18} \varepsilon:{ }^{15} \varepsilon_{\mathrm{DNF}}\right)\right)\right],
\end{aligned}
$$

$$
\mathrm{DNF}=\mathrm{DNF}_{14} \mathrm{~N}+\mathrm{DNF}_{15} \mathrm{~N}=\mathrm{DNF}_{16} \mathrm{O}+\mathrm{DNF}_{18} \mathrm{O},
$$

where $D$ refers to the molecular diffusion coefficient for $\mathrm{NO}_{3}^{-}$adjusted for porosity, DNF and NTR refer to the reaction rate of denitrification or nitrification, respectively (in mass volume ${ }^{-1}$ time $^{-1}$ ), C refers to the concentration of each isotopologue (in mass volume ${ }^{-1}$ ) and $k$ refers to the firstorder rate constant $\left(\right.$ time $\left.^{-1}\right)$. The fractionation factor, $\alpha$, is defined as the ratio of rate constants for the light isotope over the heavy isotope (e.g., ${ }^{15} \alpha={ }^{14} k /{ }^{15} k$ ) for a given process, alternatively expressed in terms of epsilon where $\varepsilon=$ $(\alpha-1) \times 1000$ in units of permil (\%o). The term ${ }^{18} \varepsilon:{ }^{15} \varepsilon_{\text {DNF }}$ refers to the degree of coupling between the $\mathrm{N}$ and $\mathrm{O}$ isotope fractionation during denitrification, with a value of 1 indicating that the two isotope effects are identical.
For the $\delta^{15} \mathrm{~N}$ and $\delta^{18} \mathrm{O}$ of nitrification (NTR)

$\mathrm{NTR}_{14} \mathrm{~N}=\mathrm{NTR} \cdot f_{14}{ }_{\mathrm{NNTR}}$

$\mathrm{NTR}_{15} \mathrm{~N}=\mathrm{NTR} \cdot f_{15} \mathrm{NNTR}$

$\mathrm{NTR}_{16 \mathrm{O}}=\mathrm{NTR} \cdot f_{16 \mathrm{ONTR}}$

$\mathrm{NTR}_{18 \mathrm{O}}=\mathrm{NTR} \cdot f_{18 \mathrm{ONTR}}$

where $f$ refers to the fractional abundance of a particular isotopologue and

$\mathrm{NTR}=\mathrm{NTR}_{14} \mathrm{~N}+\mathrm{NTR}_{15} \mathrm{~N}=\mathrm{NTR}_{16} \mathrm{O}+\mathrm{NTR}_{18} \mathrm{O}$,

$f_{14 \mathrm{NNTR}}=1 /\left(1+{ }^{15} R_{\mathrm{NTR}}\right)$,

$f_{15 \mathrm{NNTR}}=1-f_{14 \mathrm{NNTR}}$,

${ }^{15} R_{\mathrm{NTR}}=\left[{ }^{15} \mathrm{~N} /{ }^{14} \mathrm{~N}\right]_{\mathrm{NTR}}$,

and

$f_{16 \mathrm{ONTR}}=1 /\left(1+{ }^{18} R_{\mathrm{NTR}}\right)$,

$f_{18} \mathrm{ONTR}=1-f_{16} \mathrm{ONTR}$,

${ }^{18} R_{\mathrm{NTR}}=\left[{ }^{18} \mathrm{O} /{ }^{16} \mathrm{O}\right]_{\mathrm{NTR}}$,

and ${ }^{15} R_{\text {NTR }}$ and ${ }^{18} R_{\text {NTR }}$ used to calculate the $\delta^{15} \mathrm{~N}_{\mathrm{NTR}}$ and $\delta^{18} \mathrm{O}_{\mathrm{NTR}}$, respectively.

For parameterizing diffusion, we use a porewater diffusion coefficient $\left(D_{\mathrm{s}}\right)$ based on the molecular diffusion coefficient $\left(D_{\mathrm{m}}\right.$ at $5^{\circ} \mathrm{C}$ ) for $\mathrm{NO}_{3}^{-}$of $1.05 \times 10^{-5} \mathrm{~cm}^{2} \mathrm{~s}^{-1}$ ( $\mathrm{Li}$ and Gregory, 1974) adjusted for an average porosity $(\varphi)$ of North Pond sediments of $64 \%$ (Expedition-336-Scientists, 2012), where $D_{\mathrm{s}}=\varphi^{k} D_{\mathrm{m}}$ and $k$ is an empirically derived factor (we use 2.6) accounting for tortuosity of pore space (Hammond et al., 1996; McManus et al., 1995).

Compared with contemporaneous profiles of $\mathrm{O}_{2}$ and $\mathrm{Sr}$ (Orcutt et al., 2013) and other dissolved ions, the $\mathrm{NO}_{3}^{-}$ concentration profiles suffer from some apparent analytical noise. The nature of the heterogeneity for $\mathrm{NO}_{3}^{-}$concentration measurements was unclear. However, it is unlikely that this heterogeneity is environmental and we attribute it to small amounts of evaporation during freezer storage of the sediments, which is supported by the apparent smoothness of the isotopic measurements (evaporation would change the apparent concentrations without influencing the isotopic composition of solutes such as $\mathrm{NO}_{3}^{-}$). As such, for the purpose of the diffusion-reaction model, we applied a 5-point-weighted triangular smoothing to the concentration data to eliminate outliers and unrealistically sharp gradients (Fig. 2). Given the relatively smooth and contiguous vertical profiles of $\delta^{15} \mathrm{~N}_{\mathrm{NO}_{3}}$ and $\delta^{18} \mathrm{O}_{\mathrm{NO}_{3}}$, only very minor smoothing to these data was required using a similar approach (Fig. 2).

Within this model architecture, we explore the influence of four key parameters that could affect the estimation of nitrification and denitrification rates by this isotope mass balance 
approach, in particular, ${ }^{15} \varepsilon_{\mathrm{DNF}},{ }^{18} \varepsilon:{ }^{15} \varepsilon_{\mathrm{DNF}}, \delta^{15} \mathrm{~N}_{\mathrm{NTR}}$, and $\delta^{18} \mathrm{O}_{\text {NTR. }}$. Specifically, the expression of the full enzymaticlevel isotope effect $\left({ }^{15} \varepsilon_{\mathrm{DNF}}\right)$ for denitrification $(27 \%$ ) can be influenced by electron donor, carbon substrate quality, denitrification rate and metabolic activity (Kritee et al., 2012). Moreover, although the relationship between the kinetic isotope effects for ${ }^{18} \mathrm{O}$ and ${ }^{15} \mathrm{~N}$ during respiratory consumption of $\mathrm{NO}_{3}^{-}$by denitrification (e.g., ${ }^{18} \varepsilon:{ }^{15} \varepsilon_{\mathrm{DNF}}$ ) has been shown to remain consistent at $1: 1$, the potential influence of nitrate reduction by periplasmic nitrate reductase (Nap, periplasmic nitrate reductase.), which imparts a lower ${ }^{18} \varepsilon:{ }^{15} \varepsilon_{\mathrm{DNF}}$ value of 0.6 (Granger et al., 2008; Frey et al., 2014), could play a role in the dual isotope trajectory of $\mathrm{NO}_{3}^{-}$consumption (Wenk et al., 2014). Further, in the absence of $\mathrm{NH}_{4}^{+}$accumulation in these sediments, the $\delta^{15} \mathrm{~N}_{\mathrm{NTR}}$ is equal to the source of $\mathrm{NH}_{4}^{+}$being oxidized to $\mathrm{NO}_{3}^{-}$, which is related to the $\delta^{15} \mathrm{~N}$ of the organic matter being remineralized. The $\delta^{18} \mathrm{O}_{\mathrm{NTR}}$ stems from a combination of factors including the $\delta^{18} \mathrm{O}$ of the water and dissolved $\mathrm{O}_{2}$ as well as the expression of kinetic isotope effects associated with the incorporation of $\mathrm{O}$ atoms from these pools (Buchwald and Casciotti, 2010; Casciotti et al., 2010; Andersson and Hooper, 1983). Below, we use the model to optimize and predict these values and to explore the sensitivity of rate estimates to ${ }^{15} \varepsilon_{\text {DNF }}$.

The model contains more parameters than can be explicitly estimated from the small number of data points measured. To minimize the number of variables as much as possible (and maximize the utility of the approach for constraining other variables), we adapt the model implementation for three different $\mathrm{O}_{2}$ regimes: (1) oxic intervals where $\mathrm{O}_{2}$ is poised as the more energy-yielding oxidant with respect to $\mathrm{NO}_{3}^{-}$(here generally $\mathrm{O}_{2}>\sim 40 \mu \mathrm{M}$ ) and in which only nitrification is allowed to occur, (2) transitional intervals in which both denitrification and nitrification may occur $\left(\mathrm{O}_{2}\right.$ between $\sim 40$ and $2 \mu \mathrm{M}$ ) and (3) anoxic intervals where $\mathrm{O}_{2}$ is $<2 \mu \mathrm{M}$ and in which only denitrification is allowed to occur. We choose $40 \mu \mathrm{M}$ as a boundary for the onset of denitrification based on estimates of thermodynamic energy yield under these conditions for aerobic vs. denitrification-based respiration (Brewer et al., 2014). In the oxic intervals, the model is used for parameter estimation of both $\delta^{15} \mathrm{~N}_{\mathrm{NTR}}$ and $\delta^{18} \mathrm{O}_{\mathrm{NTR}}$ (in addition to nitrification rate), while in the anoxic intervals the model is used to estimate ${ }^{15} \varepsilon_{\mathrm{DNF}}$ and ${ }^{18} \varepsilon:{ }^{15} \varepsilon_{\mathrm{DNF}}$ (in addition to denitrification rate). In transitional intervals, ${ }^{15} \varepsilon_{\mathrm{DNF}}$ and ${ }^{18} \varepsilon:{ }^{15} \varepsilon_{\mathrm{DNF}}$ are held constant at $25 \%$ ond 1 , respectively, and the parameter $\delta^{15} \mathrm{~N}_{\mathrm{NTR}}$ and $\delta^{18} \mathrm{O}_{\mathrm{NTR}}$ are estimated through model fitting, together with rates of both nitrification and denitrification. In accordance with previous experimental work (Buchwald and Casciotti, 2010; Buchwald et al., 2012; Casciotti et al., 2010), the allowed range of values for $\delta^{15} \mathrm{~N}_{\mathrm{NTR}}$ and $\delta^{18} \mathrm{O}_{\mathrm{NTR}}$ were set to -5 to +10 and -5 to $+20 \%$, respectively. When ${ }^{15} \varepsilon_{\mathrm{DNF}}$ and ${ }^{18} \varepsilon:{ }^{15} \varepsilon_{\mathrm{DNF}}$ were determined by model fitting, parameter estimates were allowed to range between 0 and $30 \%$ and between 0.6 and 1.2 , respectively.

\subsection{Model results and implications}

\subsubsection{Model-estimated rates of nitrification and denitrification}

Profiles of sedimentary porewater solutes reflect the combined influence of many processes including diagenetic reactions, which are intimately related to the availability, abundance and quality of organic carbon. In particular, the distribution of dissolved substrates that are available as electron acceptors for microbial respiration of organic carbon, generally reflect stepwise consumption by the most thermodynamically (and kinetically) favorable metabolic processes (e.g., $\mathrm{O}_{2}$ consumption precedes $\mathrm{NO}_{3}^{-}$consumption, which precedes sulfate reduction). While in organic-rich estuarine and continental shelf sediments, dissolved $\mathrm{O}_{2}$ and $\mathrm{NO}_{3}^{-}$are typically consumed within a few centimeters or millimeters below the sediment-seawater interface, sediments underlying large areas of the oligotrophic ocean are characterized by very deep penetration of $\mathrm{O}_{2}$, in some cases even penetrating to the underlying ocean crust (D'Hondt et al., 2009, 2015; Orcutt et al., 2013; Ziebis et al., 2012). In connection with this deep penetration of $\mathrm{O}_{2}$, deep-sea sediment porewaters also often exhibit extensive accumulation of $\mathrm{NO}_{3}^{-}$ above ambient seawater concentrations, associated with the oxidation of $\mathrm{NH}_{4}^{+}$released by aerobic remineralization of sediment organic matter (and linked to the consumption of $\mathrm{O}_{2}$ through Redfield stoichiometry) (Berelson et al., 1990; Christensen and Rowe, 1984; D'Hondt et al., 2009; Goloway and Bender, 1982; Seitzinger et al., 1984). In organic-rich sediments, $\mathrm{NO}_{3}^{-}$concentration profiles may exhibit maxima only a few millimeters or centimeters below the sedimentwater interface. In contrast, in the deep-sea sediments underlying the oligotrophic regions of the ocean, the sedimentary zone where $\mathrm{NO}_{3}^{-}$accumulates to 10 to $30 \mu \mathrm{M}$ above bottom seawater concentrations can extend over a much larger vertical extent and nitrate maxima can be found tens of meters below the seafloor. In effect, the redox zonation of $\mathrm{O}_{2}$ respiration, $\mathrm{NH}_{4}^{+}$oxidation, $\mathrm{NO}_{2}^{-}$oxidation, and $\mathrm{NO}_{3}^{-}$reduction extends over larger depth ranges, and, depending on sediment thickness and organic carbon content - the redox state of these sediments may never reach the potential for $\mathrm{NO}_{3}^{-}$reduction to play a role as a thermodynamically viable metabolic pathway.

While it is not necessarily apparent whether any $\mathrm{NO}_{3}^{-}$ respiration is occurring based on North Pond concentration profiles alone, dramatic increases in the $\delta^{15} \mathrm{~N}$ and $\delta^{18} \mathrm{O}$ of $\mathrm{NO}_{3}^{-}$with depth into the anoxic sediment intervals were observed in both 2B and 3D (Fig. 2) - indicating isotope fractionation by microbial denitrification. The highest $\delta^{15} \mathrm{~N}$ and $\delta^{18} \mathrm{O}$ values in $2 \mathrm{~B}(+22.2$ and $+21.8 \%$, respectively) generally coincide with the lowest dissolved $\mathrm{O}_{2}$, while the highest 
$\delta^{15} \mathrm{~N}$ and $\delta^{18} \mathrm{O}$ values in $3 \mathrm{D}(+11.8$ and $+19.7 \%$, respectively) fall just below the depth of lowest $\mathrm{O}_{2}$. In stark contrast, 4A porewaters exhibit only a minor increase in $\delta^{18} \mathrm{O}$ of $\sim 2.7 \%$ within the anoxic interval, while $\delta^{15} \mathrm{~N}$ increased by only $0.8 \%$ (Fig. 2). The marked distinction between $2 \mathrm{~B} / 3 \mathrm{D}$ and $4 \mathrm{~A}$ notwithstanding, the dual isotopic composition and concentrations of $\mathrm{NO}_{3}^{-}$in these porewaters reveal active nitrogen cycling within all three sites.

Using these changes in dual $\mathrm{NO}_{3}^{-}$isotopic composition and concentration, we calculated the rates of nitrification and denitrification necessary to produce the observed patterns within each interval (in the transitional intervals, here we prescribe a value of $25 \%$ for ${ }^{15} \varepsilon_{\mathrm{DNF}}$, but explore the model sensitivity to this value later). Rates of nitrification and denitrification varied with depth, as well as across the three sites (Fig. 4; Table 1). Estimated rates of nitrification in the oxic and transitional intervals were up to $871 \mathrm{nmol} \mathrm{cm}^{-3} \mathrm{yr}^{-1}$, while rates of denitrification in the anoxic and transitional intervals reached up to $579 \mathrm{nmol} \mathrm{cm}^{-3} \mathrm{yr}^{-1}$ (Fig. 4; Table 1). By comparison, maximum rates of nitrification estimated from $\mathrm{O}_{2}$ and $\mathrm{NO}_{3}^{-}$profiles in sediments below the South $\mathrm{Pa}$ cific gyre, perhaps the most organic-matter-depleted seafloor sediments in the world, were predicted to be only as high as 18-74 $\mathrm{nmol} \mathrm{cm}^{-3} \mathrm{yr}^{-1}$ (D'Hondt et al., 2009). The estimated nitrification rates at North Pond are still orders of magnitude lower than those typically measured in coastal and estuarine sediments (Rysgaard et al., 1993; Usui et al., 2001; Wankel et al., 2011), and are, thus, consistent with lower total cell abundances and lower abundance of functional genes involved in nitrification recently measured in North Pond sediments (Zhao and Jørgensen, 2015) as compared to typical estuarine sediments (Mosier and Francis, 2008; Wankel et al., 2011).

In general, nitrification rates in the oxic intervals near the seafloor were comparable to rates in the oxic layers near the underlying crust. The highest denitrification rates typically coincided with depths where the lowest $\mathrm{O}_{2}$ was observed, with the exception of rather low rates near the central anoxic zone of core $2 \mathrm{~B}$. Nitrification, which requires $\mathrm{O}_{2}$, is observed as deep as $28 \mathrm{~m}$ in $2 \mathrm{~B}$ and all the way to the underlying crust at the other two sites. Interestingly, modeled rates of nitrification were typically the highest at comparatively low levels of dissolved $\mathrm{O}_{2}(\sim 15 \mu \mathrm{M}$ in $2 \mathrm{~B}, \sim 10 \mu \mathrm{M}$ in $3 \mathrm{D}$ and $\sim 35 \mu \mathrm{M}$ in $4 \mathrm{~A}$ ) - suggesting an important role for micro-aerophillic nitrification (e.g., organisms adapted to respiration under low $\mathrm{O}_{2}$ conditions). The depths of maximum denitrification rates generally coincided with the onset of $\mathrm{O}_{2}$ levels below $\sim 2 \mu \mathrm{M}$. In $2 \mathrm{~B}$, denitrification rates were the highest at depths of $\sim 28$ and $\sim 72 \mathrm{~m}$ (Fig. 4). In 3D, maximum denitrification rates were observed at $21 \mathrm{~m}$ - with similar rates between 20 and $25 \mathrm{~m}$. Interestingly, the model indicated no denitrification within the $3 \mathrm{~m}$ anoxic zone of this core - possibly indicating limitation by organic substrate availability. In contrast, rates of denitrification were only estimated to occur within the anoxic zone of site $4 \mathrm{~A}$ (e.g., not within the transitional intervals, although this was somewhat sensitive to prescribed ${ }^{15} \varepsilon_{\mathrm{DNF}}$, see below), with the highest rate of $24 \mathrm{nmol} \mathrm{cm}{ }^{-3} \mathrm{yr}^{-1}$ at a depth of $44 \mathrm{~m}$. Overall, rates of both nitrification and denitrification were highest at site 2B and lowest in $4 \mathrm{~A}$, consistent with a greater amount of microbial activity revealed by the steeper $\mathrm{O}_{2}$ gradients in $2 \mathrm{~B}$ and recent functional gene quantification in NP sediments (Zhao and Jørgensen, 2015). More precisely, the abundance of $16 \mathrm{~S}$ $r$ RNA, and several functional genes, including those for both archaeal and bacterial ammonia oxidation, nitrite oxidation, and denitrification, were all significantly lower in 4A than in the other cores (Zhao and Jørgensen, 2015). In all three cores, maximum rates of nitrification exceeded those of denitrification, consistent with the net accumulation of $\mathrm{NO}_{3}^{-}$throughout the sediment column. Even in $2 \mathrm{~B}$, where $\mathrm{O}_{2}$ is below $2 \mu \mathrm{M}$ over an interval of $\sim 40 \mathrm{~m}$, the $\mathrm{NO}_{3}^{-}$concentration profile exhibits no obvious influence by $\mathrm{NO}_{3}^{-}$reduction (Fig. 2).

Finally, the model suggests the co-occurrence of nitrification and denitrification (Fig. 4) in the transition zones of our model (depths at which $\mathrm{O}_{2}$ is between 2 and $40 \mu \mathrm{M}$ ). Although denitrification rates generally did not exceed those of nitrification where the two processes are co-occurring (i.e., no net nitrate consumption), the increasing $\delta^{15} \mathrm{~N}$ and $\delta^{18} \mathrm{O}$ of $\mathrm{NO}_{3}^{-}$clearly reflects the influence of $\mathrm{NO}_{3}^{-}$loss via denitrification. Indeed, similar inferences have also been made about such overlap of nitrification and denitrification albeit in the much deeper and organic-rich hadopelagic sediments of the Ogasawara Trench (Nunoura et al., 2013). This observation illustrates the exceptionally extended vertical redox zonation of these sediments - and highlights the potential interaction between nitrogen transformations that are classically considered spatially explicit.

\subsubsection{Model-predicted values of $\delta^{15} \mathrm{~N}_{\mathrm{NTR}}$ : implications for $\mathrm{N}$ sources and processes in oligotrophic sediments}

In general, where $\mathrm{NH}_{4}^{+}$from remineralization does not accumulate, it is expected that the $\delta^{15} \mathrm{~N}$ of $\mathrm{NO}_{3}^{-}$produced by $\mathrm{NH}_{4}^{+}$oxidation will be equivalent to the $\delta^{15} \mathrm{~N}$ of the $\mathrm{NH}_{4}^{+}$ deriving from remineralization of organic nitrogen. The $\delta^{15} \mathrm{~N}$ of organic $\mathrm{N}$ of the North Pond sediments was not quantified in this study ( $\mathrm{N}$ content as measured by Ziebis et al. (2012) within the upper $8 \mathrm{~m}$ was $<0.03 \%$ ). Yet, the average modelpredicted $\delta^{15} \mathrm{~N}$ of newly produced $\mathrm{NO}_{3}^{-}\left(\delta^{15} \mathrm{~N}_{\mathrm{NTR}}\right)$ (Fig. 5) ranged from -3.1 to $+1.1 \%$ (standard error typically \pm 0.3 to $0.4 \%$ ), generally lower than that expected based on the $\delta^{15} \mathrm{~N}$ of sinking organic matter from the surface ocean of $\sim+3.7 \%$ o (Altabet, 1988, 1989; Knapp et al., 2005; Ren et al., 2012). Values of $\delta^{15} \mathrm{~N}_{\mathrm{NTR}}>+1 \%$ o were only observed just above the $\mathrm{O}_{2}$ minimum at sites $2 \mathrm{~B}$ and 3D (Fig. 5).

Confronted with this difference, we turn to other factors that might play a role in setting the $\delta^{15} \mathrm{~N}_{\mathrm{NTR}}$. The lower $\delta^{15} \mathrm{~N}$ values of newly produced $\mathrm{NO}_{3}^{-}$can potentially be explained by a number of possible processes including: (1) isotopic fractionation during remineralization, (2) competitive 


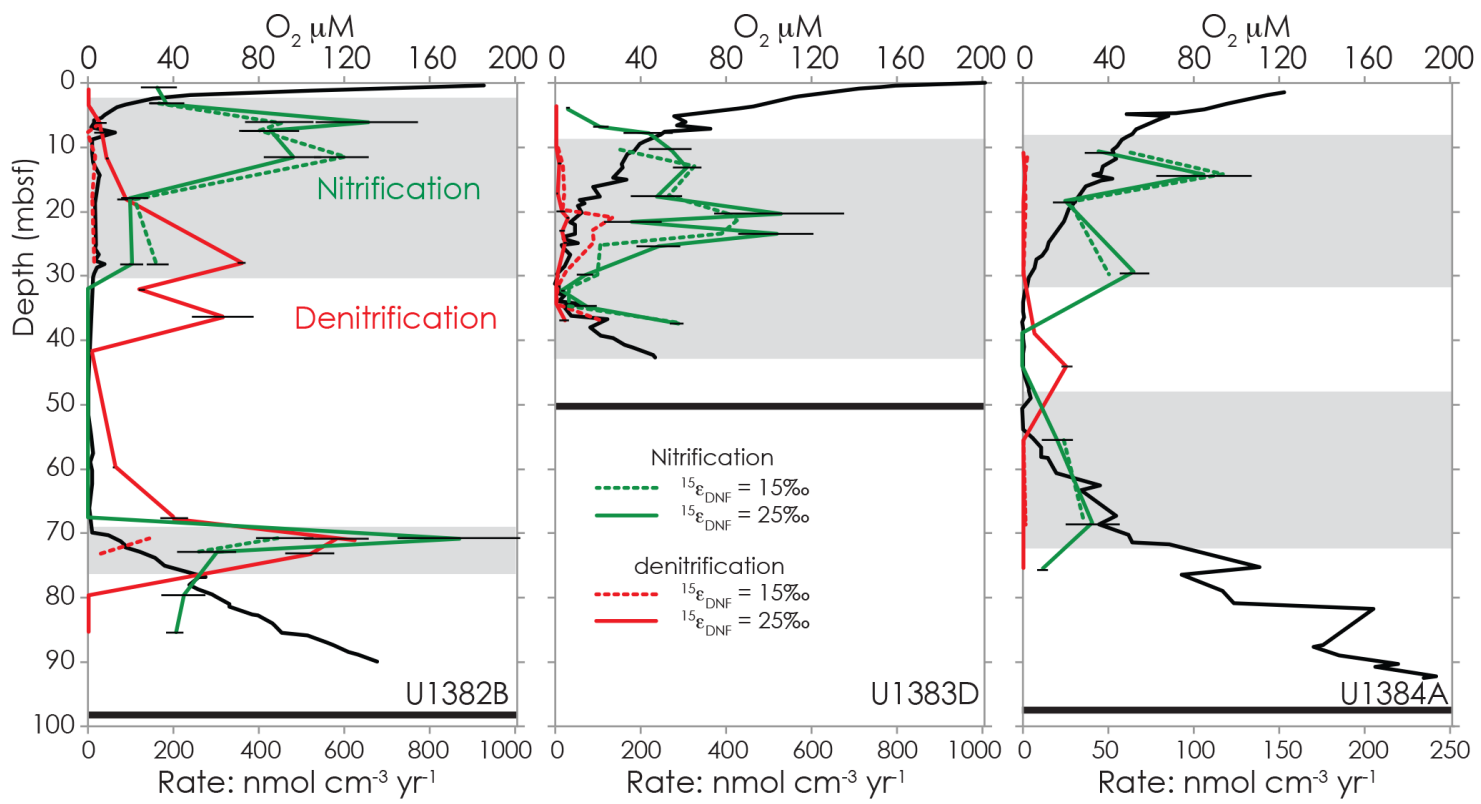

Figure 4. Model-estimated rates of denitrification and nitrification ( $\mathrm{nmol} \mathrm{cm}{ }^{-3} \mathrm{yr}^{-1}$ ) based on fitting of nitrate concentration and $\mathrm{N}$ and $\mathrm{O}$ isotopic composition. Estimates within transitional intervals are calculated using a value for ${ }^{15} \varepsilon_{\text {DNF }}$ of either $15 \%$ (dashed) or $25 \%$ (solid). Error bars are shown for the ${ }^{15} \varepsilon_{\mathrm{DNF}}=25 \%$ only and indicate the standard error of 10 model runs (see text). Note the different scales for rates among the three profiles.

branching between $\mathrm{NH}_{4}^{+}$oxidation (whether anaerobic or aerobic) and $\mathrm{NH}_{4}^{+}$assimilation or (3) contribution of low $\delta^{15} \mathrm{~N}$ through organic matter derived from sedimentary $\mathrm{N}_{2}$ fixation.

Nitrogen isotope fractionation during organic matter remineralization has been reported (Altabet, 1988; Altabet et al., 1999; Estep and Macko, 1984; Lehmann et al., 2002), whereby the preferential remineralization of low $\delta^{15} \mathrm{~N}$ organic matter leads to production of low $\delta^{15} \mathrm{~N} \mathrm{NH}_{4}^{+}$(which could feed into the production of low $\delta^{15} \mathrm{~N} \mathrm{NO}_{3}^{-}$). The influence of this phenomenon is more likely, however, during remineralization of fresh organic matter and where the heterotrophic community has abundant access to highly labile proteinaceous organic matter (Altabet, 1988; Estep and Macko, 1984). At North Pond, given the extremely low levels of organic material present in the sediments, it seems unlikely that preferential utilization of low $\delta^{15} \mathrm{~N}$ organic material during diagenesis is responsible for the low $\delta^{15} \mathrm{~N}_{\mathrm{NTR}}$.

Competitive branching of $\mathrm{NH}_{4}^{+}$supporting simultaneous nutritional supply (as an $\mathrm{N}$ source) and energy supply (via autotrophic ammonia oxidation) has been used to explain $\mathrm{NO}_{3}^{-}$ dual isotopic signatures in N-rich surface waters (Wankel et al., 2007). Because $\mathrm{N}$ isotope fractionation during ammonia oxidation is generally thought to be stronger than that of $\mathrm{NH}_{4}^{+}$assimilation by phytoplankton under surfacewater conditions, it was argued that this competitive branching can lead to a shunt of low $\delta^{15} \mathrm{~N}$ into the $\mathrm{NO}_{3}^{-}$pool via ammonia oxidation (Wankel et al., 2007). In contrast to the high-nutrient, sunlit, productive waters of Monterey Bay, however, under the energy-limited, and extremely low- $\mathrm{NH}_{4}^{+}$production conditions in North Pond porewaters, it is not clear whether the same mechanisms of $\mathrm{NH}_{4}^{+}$partitioning are operating.

Although North Pond porewaters contain abundant $\mathrm{NO}_{3}^{-}$, assimilation of $\mathrm{NO}_{3}^{-}$as a nutritional $\mathrm{N}$ source requires an associated metabolic energy for reduction of $\mathrm{NO}_{3}^{-}$(via an assimilatory nitrate reductase), a costly process in this energypoor environment. On the other hand, although $\mathrm{NH}_{4}^{+}$is more easily assimilated by most microbes, its low abundance in North Pond porewaters reflect its scarcity as a source of $\mathrm{N}$ required for cell growth. Based on the estimated values of the $\mathrm{N}$ isotope effect for $\mathrm{NO}_{3}^{-}$consumption (by denitrification) in the porewaters of $2 \mathrm{~B}$ that average $\sim 20 \%$ o (Table 2 ), there is little suggestion of $\mathrm{NO}_{3}^{-}$assimilation, which would lead to much lower estimated values of ${ }^{15} \varepsilon_{\mathrm{DNF}}$ (Granger et al., 2010). Thus, it is more likely that nutritional $\mathrm{N}$ originates from a reduced form such as $\mathrm{NH}_{4}^{+}$and/or organic $\mathrm{N}$. If the $\mathrm{N}$ isotope effect for ammonia oxidation is much larger than that of ammonia assimilation, then such a competitive branching effect may also be contributing to a low $\delta^{15} \mathrm{~N}_{\mathrm{NTR}}$. Although under such low concentrations, it is likely that microbial acquisition of $\mathrm{NH}_{4}^{+}$(whether for assimilation or for oxidation) is diffusion-limited, conditions under which the $\mathrm{N}$ isotope effect is expected to be near $0 \%$ (Hoch et al., 1992); a strong difference in the isotope effects for assimilation and oxidation of $\mathrm{NH}_{4}^{+}$could still contribute to the production of low $\delta^{15} \mathrm{~N}$ nitrate. 


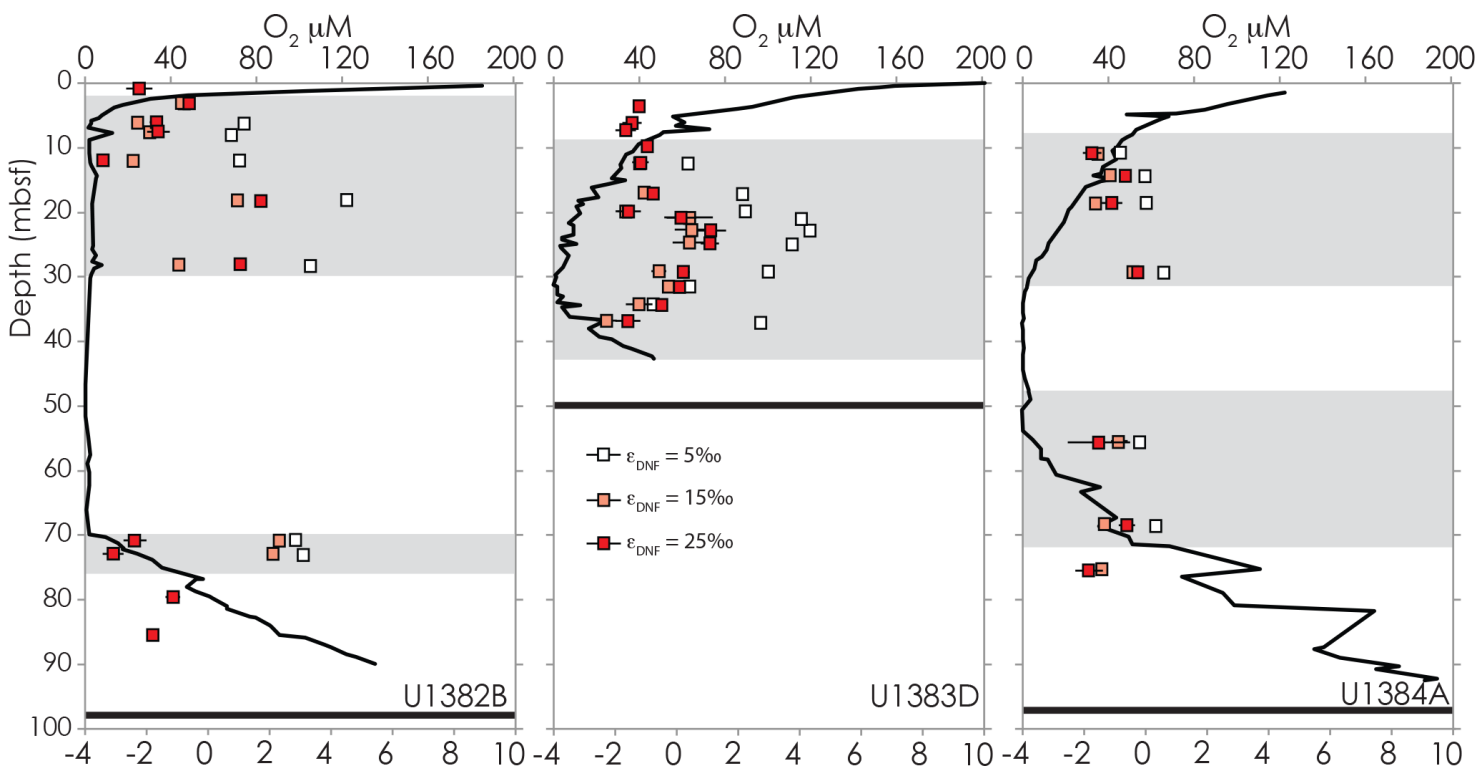

Figure 5. Model-estimated values for the $\mathrm{N}$ isotopic composition of new nitrate produced by nitrification $\left(\delta^{15} \mathrm{~N}_{\mathrm{NTR}}\right)$ occurring within porewaters. Values are calculated for depths at which $\mathrm{O}_{2}$ concentrations were $>2 \mu \mathrm{M}$ (e.g., oxic and transitional intervals). Sensitivity of $\delta^{15} \mathrm{~N}_{\mathrm{NTR}}$ to prescribed values of the isotope effect for denitrification $\left({ }^{15_{\varepsilon}} \varepsilon_{\mathrm{DNF}}\right)$ in transitional intervals, where both nitrification and denitrification can co-occur, is also indicated.

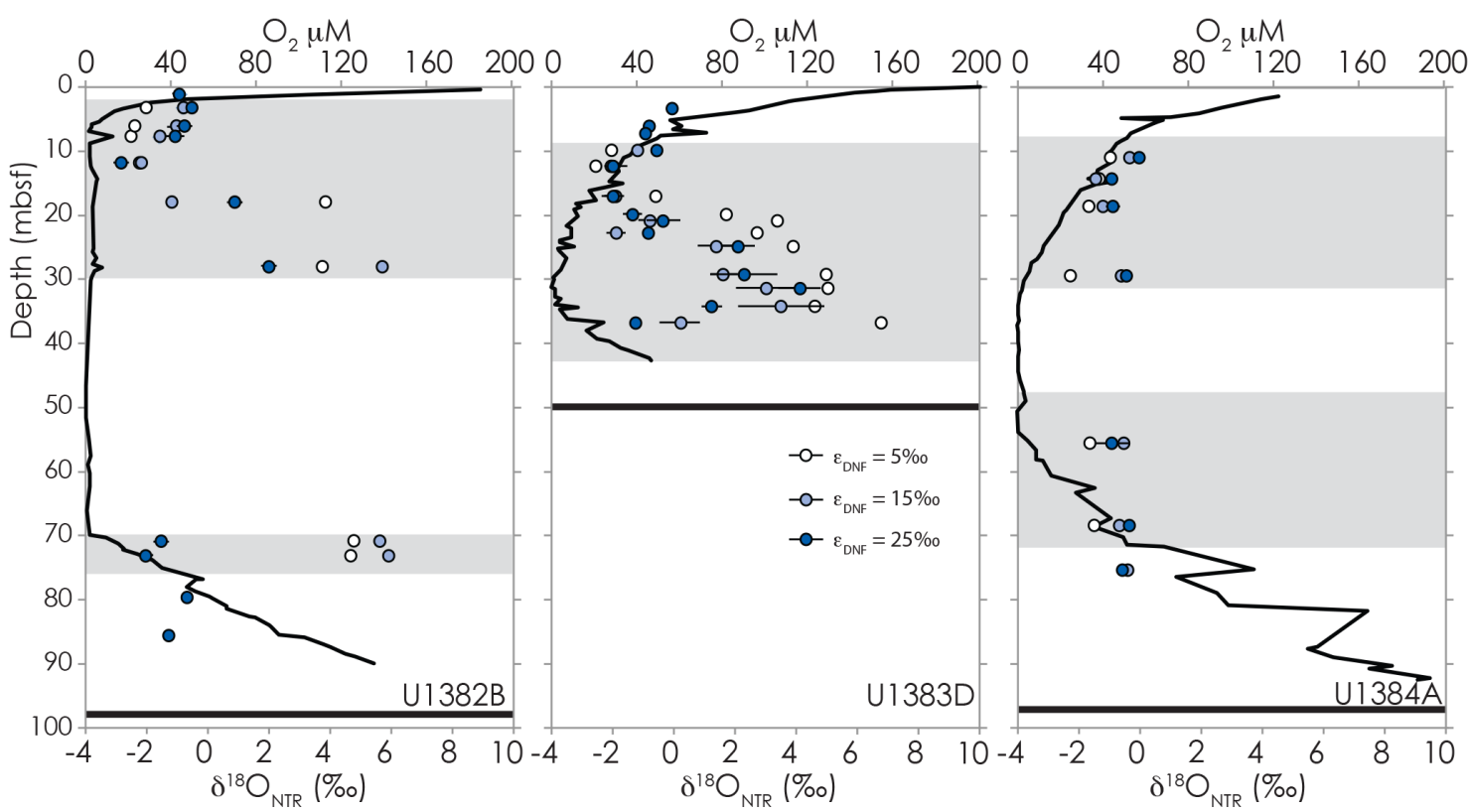

Figure 6. Model-estimated values for the $\mathrm{O}$ isotopic composition of new nitrate produced by nitrification $\left(\delta^{18} \mathrm{O}_{\mathrm{NTR}}\right)$ occurring within porewaters. Values are calculated for depths at which $\mathrm{O}_{2}$ concentrations were $>2 \mu \mathrm{M}$ (e.g., oxic and transitional intervals). Sensitivity of $\delta^{18} \mathrm{O}_{\mathrm{NTR}}$ to prescribed values of the isotope effect for denitrification $\left({ }^{15} \varepsilon_{\mathrm{DNF}}\right)$ in transitional intervals, where both nitrification and denitrification can co-occur, is also indicated. 
Table 2. Denitrification isotope effects ${ }^{15} \varepsilon_{\mathrm{DNF}}$ and ${ }^{18} \varepsilon:{ }^{15} \varepsilon_{\mathrm{DNF}}$ estimated from anoxic porewaters at North Pond.

\begin{tabular}{lrrr}
\hline & & \multicolumn{2}{c}{ Denitrification parameters } \\
\cline { 3 - 4 } Core ID & Depth m b.s.f. & ${ }^{15} \varepsilon_{\text {DNF }}$ & ${ }^{18} \varepsilon_{\text {DNF: }}{ }^{15}$ DNF \\
\hline U1382B & 32.1 & $21.0 \pm 0.3$ & $0.99 \pm 0.02$ \\
U1382B & 36.3 & $21.9 \pm 0.4$ & $0.95 \pm 0.02$ \\
U1382B & 41.6 & $20.7 \pm 0.1$ & $0.84 \pm 0.01$ \\
U1382B & 59.8 & $18.8 \pm 0.3$ & $1.07 \pm 0.02$ \\
U1382B & 67.7 & $17.4 \pm 0.4$ & $1.11 \pm 0.02$ \\
U1384A & 38.8 & $*$ & $*$ \\
U1384A & 44.1 & $8.1 \pm 0.2$ & $1.08 \pm 0.04$ \\
\hline
\end{tabular}

${ }^{*}$ Changes in $\delta^{15} \mathrm{~N}$ and $\delta^{18} \mathrm{O}$ were too small over this interval for resolving a reliable estimate of ${ }^{15} \varepsilon$ or ${ }^{18} \varepsilon:{ }^{15} \varepsilon$

A final possibility for the low values of $\delta^{15} \mathrm{~N}_{\mathrm{NTR}}$ could reflect the relative importance of benthic $\mathrm{N}_{2}$ fixation operating in North Pond sediments. Bacterial $\mathrm{N}_{2}$ fixation is generally thought to result in biomass having a $\delta^{15} \mathrm{~N}$ between -2 and $0 \%$ (Delwiche et al., 1979; Meador et al., 2007; Minigawa and Wada, 1986), which could effectively introduce new $\mathrm{N}$ and decrease the bulk $\delta^{15} \mathrm{~N}$ available for oxidation. Benthic $\mathrm{N}_{2}$ fixation is not generally considered to be an important enough contributor to the total sediment organic matter to influence the bulk $\delta^{15} \mathrm{~N}$ values of sediment organic matter. However, given the low organic-matter flux to these sediments from the overlying oligotrophic surface waters, a proportionately smaller amount of $\mathrm{N}_{2}$ fixation would be required to significantly impact the sediment organic $\delta^{15} \mathrm{~N}$ value. While $\mathrm{N}_{2}$ fixation is an energetically costly metabolism and might seem an unlikely strategy given the abundant porewater $\mathrm{NO}_{3}^{-}$pool, it has been recently acknowledged that $\mathrm{N}_{2}$ fixation in benthic environments may be widely underestimated, despite high levels of porewater DIN including $\mathrm{NO}_{3}^{-}$and/or $\mathrm{NH}_{4}^{+}$(Knapp, 2012).

In fact, $\mathrm{N}_{2}$ fixation could be ecologically favored in organic-lean sediments like those at North Pond owing to the formation of $\mathrm{H}_{2}$ as an end product, which might afford some community level. Although primarily recycled by highly efficient hydrogenases in $\mathrm{N}$-fixing bacteria (Bothe et al., 2010), a small efflux of $\mathrm{H}_{2}$ could help to fuel other autotrophic metabolisms including both $\mathrm{NO}_{3}^{-}$reduction (Nakagawa et al., 2005) or the Knallgas reaction $\left(\mathrm{H}_{2}+\mathrm{O}_{2}\right)$, perhaps providing some mutualistic benefit. Hydrogen-based metabolism has been proposed as a significant contributor to subsurface autotrophy underlying the oligotrophic South Pacific gyre (D'Hondt et al., 2009). Although the involvement of so-called alternative nitrogenases (the $\mathrm{Fe}$ and $\mathrm{V}$ forms), which have been shown to display an even larger kinetic isotope effect ( -6 to $-7 \%$ o) than the Mo-bearing form (Zhang et al., 2014), could offer even greater leverage on lowering of the bulk $\delta^{15} \mathrm{~N}$ (and source of $\mathrm{N}$ for nitrification), their involvement in non-sulfidic marine systems, where Mo is re- plete and soluble Fe and V is scarce, is expected to be minimal (Zhang et al., 2014). A similar argument was also made for the cryptic involvement of $\mathrm{N}_{2}$ fixation as source of low $\delta^{15} \mathrm{~N}$ and explanation for dual $\mathrm{NO}_{3}^{-}$isotopic patterns in the large oxygen minimum zone of the eastern tropical North $\mathrm{Pa}$ cific (Sigman et al., 2005). Thus, we conclude that the low predicted values of $\delta^{15} \mathrm{~N}_{\mathrm{NTR}}$ provide compelling evidence for an important role of in situ $\mathrm{N}_{2}$ fixation in these organiclean sediments.

Finally, there is a conspicuous increase in the predicted $\delta^{15} \mathrm{~N}_{\mathrm{NTR}}$ at sites 2B and 3D (up to +1.8 and $+1.1 \%$, respectively) between 15 and $35 \mathrm{~m}$. Although we have no compelling explanation for these observations, it is interesting that these values coincide with the transitional intervals over which $\delta^{18} \mathrm{O}_{\mathrm{NO}_{3}}$ values increase much more rapidly than $\delta^{15} \mathrm{~N}_{\mathrm{NO}_{3}}$. While it is possible that our model is insufficient, it may also be that these suboxic depths support differential amounts of in situ nitrogen fixation leading to shifts in the bulk $\delta^{15} \mathrm{~N}$ available for oxidation by nitrification.

The contribution of competitive branching during $\mathrm{NH}_{4}^{+}$ consumption notwithstanding, the predicted $\delta^{15} \mathrm{~N}_{\mathrm{NTR}}$ values can serve as an index of the degree of organic matter deriving from in situ $\mathrm{N}_{2}$ fixation versus delivery from the overlying water $\left(\delta^{15} \mathrm{~N} \sim+3.7 \%\right.$ o). Indeed, using a value of $-2 \%$ o to represent organic matter derived from biological $\mathrm{N}_{2}$ fixation (Delwiche et al., 1979; Meador et al., 2007; Minigawa and Wada, 1986), our results suggest that between 25 and $100 \%$ (with an average of $80 \pm 20 \%$ ) of the organic nitrogen supply in these sediments from biological nitrogen fixation, representing a potentially enormous relative role for in situ autotrophy in sustaining these microbial communities. Under an assumption of steady state, and ignoring a potential contribution of competitive branching in $\mathrm{NH}_{4}^{+}$consumption, rates of $\mathrm{N}_{2}$ fixation were estimated as a fraction of nitrification and ranged up to $345 \mathrm{nmol} \mathrm{cm}^{-3} \mathrm{yr}^{-1}$ (Table 1). The distribution of $\mathrm{N}_{2}$ fixation rates were generally similar to nitrification - with much lower rates $\left(8-45 \mathrm{nmol} \mathrm{cm}^{-3} \mathrm{yr}^{-1}\right)$ at site $4 \mathrm{~A}$ - again consistent with overall lower cell abundance (Zhao and Jørgensen, 2015). These rates are 2-3 orders of magnitude lower than rates measured in coastal and estuarine sediments (e.g., Bertics et al., 2010; Rao and Charette, 2012; Joye and Paerl, 1993), although still much higher than rates measured in studies of $\mathrm{N}_{2}$ fixation in oligotrophic water column (e.g., Montoya et al., 2004; Capone et al., 2005). Overall, North Pond sediments appear to harbor a spectrum of microbially mediated $\mathrm{N}$ transformations, with rates lower than those found in most sedimentary systems, yet still generally higher than those observed in overlying oligotrophic waters. Thus, while the influence of both sediment hosted $\mathrm{N}_{2}$ fixation and competitive branching during $\mathrm{NH}_{4}^{+}$consumption may not be mutually exclusive, our analysis places important upper limits on the nature of autotrophic lifestyles (including $\mathrm{N}_{2}$ fixation) and the nitrogen economy in the deep subsurface. 


\subsubsection{Model-predicted values of the $\delta^{18} \mathrm{O}$ of nitrification $\left(\delta^{18} \mathbf{O}_{\mathrm{NTR}}\right)$}

We also observed variation in estimated values of the $\delta^{18} \mathrm{O}$ of newly produced $\mathrm{NO}_{3}^{-}\left(\delta^{18} \mathrm{O}_{\mathrm{NTR}}\right)$, ranging from -2.8 to as high as $+4.1 \%$ (at the $\mathrm{O}_{2}$ minimum in $3 \mathrm{D}$ ), which may offer some insight into the nature of nitrification in these sediments and the deep ocean in general. The oxygen isotope composition of newly produced $\mathrm{NO}_{3}^{-}$reflects the combination of several complex factors including (1) the $\delta^{18} \mathrm{O}$ of the ambient water and dissolved $\mathrm{O}_{2}$, (2) kinetic isotope effects during the enzymatically catalyzed incorporation of $\mathrm{O}$ atoms during oxidation of $\mathrm{NH}_{4}^{+}$and $\mathrm{NO}_{2}^{-}$, as well as (3) the potential influence of oxygen isotope equilibration between water and $\mathrm{NO}_{2}^{-}$(Casciotti et al., 2010).

In the upper profile of site $2 \mathrm{~B}$ and throughout the profile of site $4 \mathrm{~A}$, predicted values of $\delta^{18} \mathrm{O}_{\mathrm{NTR}}$ clustered between -2.8 and $0.0 \%$ with no clear trends related to downcore concentrations of $\mathrm{O}_{2}$ or $\mathrm{NO}_{3}^{-}$(Fig. 6). Although slightly lower, this range of values agrees remarkably well with values predicted by experiments using a co-culture of $\mathrm{NH}_{4}^{+}$ and $\mathrm{NO}_{2}^{-}$oxidizing bacteria, which ranged from -1.5 to $+1.3 \%$ (Buchwald et al., 2012). In systems where $\mathrm{NH}_{4}^{+}$ and $\mathrm{NO}_{2}^{-}$oxidizing bacteria co-exist and are not substratelimited, $\mathrm{NO}_{2}^{-}$does not generally accumulate and the importance of oxygen isotope equilibration between $\mathrm{NO}_{2}^{-}$and water can be considered minor ( 3\%) (Buchwald et al., 2012). In this case, the $\delta^{18} \mathrm{O}_{\mathrm{NTR}}$ is primarily set by the $\delta^{18} \mathrm{O}$ of water (seawater $\delta^{18} \mathrm{O} \sim 0 \%$ ) and dissolved $\mathrm{O}_{2}(\sim+26.4 \%$ o for the deep N. Atlantic; Kroopnick et al., 1972) and the three kinetic isotope effects during the sequential oxidation of $\mathrm{NH}_{4}^{+}$ to $\mathrm{NO}_{3}^{-}$(Buchwald et al., 2012; Casciotti et al., 2010). The resulting $\delta^{18} \mathrm{O}_{\mathrm{NTR}}$ can be described as

$$
\begin{aligned}
& \delta^{18} \mathrm{O}_{\mathrm{NTR}}=1 / 3\left[\delta^{18} \mathrm{O}_{\mathrm{O}_{2}}-\left({ }^{18} \varepsilon_{\mathrm{O}_{2}}\right)\right]+1 / 3\left[\delta^{18} \mathrm{O}_{\text {water }}\right. \\
& \left.-\left({ }^{18} \varepsilon_{\mathrm{H}_{2} \mathrm{O}, 1}\right)\right]+1 / 3\left[\delta^{18} \mathrm{O}_{\text {water }}-{ }^{18} \varepsilon_{\mathrm{H}_{2} \mathrm{O}, 2}\right]
\end{aligned}
$$

where ${ }^{18} \varepsilon$ is the kinetic isotope effect of $\mathrm{O}$ atom incorporation from $\mathrm{O}_{2}$ during $\mathrm{NH}_{4}^{+}$oxidation to $\mathrm{NH}_{2} \mathrm{OH}\left({ }^{18} \varepsilon_{\mathrm{O}_{2}}\right)$, and from water during $\mathrm{NH}_{2} \mathrm{OH}$ oxidation to $\mathrm{NO}_{2}^{-}\left({ }^{18} \varepsilon_{\mathrm{H}_{2} \mathrm{O}, 1}\right)$ and $\mathrm{NO}_{2}^{-}$oxidation to $\mathrm{NO}_{3}^{-}\left({ }^{18} \varepsilon_{\mathrm{H}_{2} \mathrm{O}, 2}\right)$ (Buchwald et al., 2012).

While the value of seawater $\delta^{18} \mathrm{O}$ can be considered to be relatively constant $(\sim 0 \%)$ in North Pond porewaters, the respiratory consumption of $\mathrm{O}_{2}$, as evident in the observed concentration profiles, imparts a relatively strong isotopic fractionation (Bender, 1990; Kroopnick and Craig, 1976; Lehmann et al., 2009) and will cause elevated $\delta^{18} \mathrm{O}_{\mathrm{O}_{2}}$ values. Using a separate reaction-diffusion model (not shown), we estimated the $\delta^{18} \mathrm{O}_{\mathrm{O}_{2}}$ to be as high as $+70 \%$ where concentrations of $\mathrm{O}_{2}$ have been drawn down $>95 \%$ of the level found in bottom seawater. Incorporation of this highly ${ }^{18} \mathrm{O}$ enriched $\mathrm{O}_{2}$ by nitrification in these low $\mathrm{O}_{2}$ intervals may contribute to observed increases in $\delta^{18} \mathrm{O}_{\mathrm{NTR}}$ predicted by our model. In particular, in the low $\mathrm{O}_{2}$ intervals of $2 \mathrm{~B}$ and $3 \mathrm{D}$, $\delta^{18} \mathrm{O}_{\mathrm{NTR}}$ values as high as $+4.1 \%$ at the four intervals coinciding with the maximum $\mathrm{O}_{2}$ drawdown (Fig. 6), and thus may point to incorporation of high- $\delta^{18} \mathrm{O} \mathrm{O}_{2}$. For example, assuming a $\delta^{18} \mathrm{O}$ value of $0 \%$ for seawater, using Eq. (11) and a combined isotope effect of $18 \%$ for the two steps of $\mathrm{NH}_{4}^{+}$oxidation to $\mathrm{NO}_{2}^{-}\left({ }^{18} \varepsilon_{\mathrm{O}_{2}}+{ }^{18} \varepsilon_{\mathrm{H}_{2} \mathrm{O}, 1}\right.$; the two have not yet been resolved from one another; Casciotti et al., 2010) and a value of $15 \%$ of ${ }^{18} \varepsilon_{\mathrm{H}_{2} \mathrm{O}, 2}$ (O atom incorporation during $\mathrm{NO}_{2}^{-}$oxidation to $\mathrm{NO}_{3}^{-}$; Buchwald et al., 2012), $\delta^{18} \mathrm{O}_{\mathrm{NTR}}$ values of $-2 \%,+2$, or $+6 \%$ o would imply incorporation of $\mathrm{O}$ from an $\mathrm{O}_{2}$ pool with a value of $\sim+45,+57$, or $+69 \%$, respectively.

If these higher values are indeed the result of enriched $\mathrm{O}_{2}$ incorporation, then they also provide indirect information on the degree of oxygen isotope equilibration occurring between $\mathrm{NO}_{2}^{-}$and water. Specifically, if some proportion of an elevated $\delta^{18} \mathrm{O}_{\mathrm{O}_{2}}$ signal is propagated into the $\mathrm{NO}_{3}^{-}$pool, then this suggests that the intermediate $\mathrm{NO}_{2}^{-}$pool did not completely equilibrate with ambient water (which would effectively erase all signs of precursor molecule $\delta^{18} \mathrm{O}$ ). Within these low $\mathrm{O}_{2}$ transitional intervals in $2 \mathrm{~B}$ and $3 \mathrm{D}$, it appears that the turnover of the very small $\mathrm{NO}_{2}^{-}$intermediate pool may be faster than the time required for complete equilibration between $\mathrm{NO}_{2}^{-}$and water (Buchwald and Casciotti, 2013). In contrast, the low $\mathrm{O}_{2}$ interval from site $4 \mathrm{~A}$ does not exhibit elevated $\delta^{18} \mathrm{O}_{\mathrm{NTR}}$ values near the oxygen minimum, perhaps suggesting that the turnover of $\mathrm{NO}_{2}^{-}$here is slower (allowing complete equilibration) or that equilibration is biologically catalyzed (e.g., enhanced by enzymatic activity; Buchwald et al., 2012). Although the concentrations of the $\mathrm{NO}_{2}^{-}$pool were generally below detection, making the accurate determination of its turnover time impossible (via $\delta^{18} \mathrm{O}$ ), the use of $\mathrm{NO}_{2}^{-}$oxygen isotopes as an independent measure of metabolic processes where concentrations persist at measurable levels may be a potentially powerful indicator of biological turnover of $\mathrm{NO}_{2}^{-}\left(\delta^{15} \mathrm{~N}\right.$ and $\delta^{18} \mathrm{O}$ of $\mathrm{NO}_{2}^{-}$in $2 \mathrm{~B}$, where $\mathrm{NO}_{2}^{-}$was detected at two depths, were not determined as part of this study). Future studies should target this pool as a complementary dimension for constraining subsurface biosphere metabolic rates.

\subsubsection{Model sensitivity to prescribed ${ }^{15} \varepsilon_{\mathrm{DNF}}$ in transitional intervals}

In the transitional intervals, where both nitrification and denitrification are allowed to co-occur, the model is underdetermined and requires some variables to be prescribed. We chose to prescribe a value for the kinetic isotope effect of denitrification $\left({ }^{15} \varepsilon_{\mathrm{DNF}}\right)$ and here examine the sensitivity of estimated rates nitrification and denitrification, as well as predicted values of $\delta^{15} \mathrm{~N}_{\mathrm{NTR}}$ and $\delta^{18} \mathrm{O}_{\mathrm{NTR}}$. Given the rather tightly confined range of determined values for ${ }^{15} \varepsilon_{\mathrm{DNF}}$ in the anoxic zone of site $2 \mathrm{~B}$, averaging $20 \pm 1.8 \%$, for illustration, we bracket our prescribed ${ }^{15} \varepsilon_{\mathrm{DNF}}$ in transitional intervals with values of 15 and $25 \%$ o (rate estimates where the 
prescribed ${ }^{15} \varepsilon_{\mathrm{DNF}}$ is as low as $5 \%$ are given in Table 1 ). Overall, the model-predicted rates of nitrification and denitrification, as well as values of $\delta^{15} \mathrm{~N}_{\mathrm{NTR}}$ and $\delta^{18} \mathrm{O}_{\mathrm{NTR}}$ were largely insensitive to changes in the prescribed strength of the isotope effect for denitrification $\left({ }^{15} \varepsilon_{\text {DNF }}\right)$ (Fig. 4).

Specifically, when the prescribed value of ${ }^{15} \varepsilon_{\mathrm{DNF}}$ decreased from 25 to $15 \%$, changes in the predicted values of $\delta^{15} \mathrm{~N}_{\mathrm{NTR}}$ and $\delta^{18} \mathrm{O}_{\mathrm{NTR}}$ were generally small (Figs. 5 and 6 ), varying by a maximum of $0.9 \%$ (average $0.5 \%$ ) and $2.3 \% o(0.6 \%)$, respectively. An exception to this is the intervals bracketing the anoxic zone of the profile at site $2 \mathrm{~B}$ (at depths of 27.9 and $70.8,72.9 \mathrm{~m}$ ), which yielded predicted $\delta^{15} \mathrm{~N}_{\mathrm{NTR}}$ that were either $2.1 \%$ o lower (at $27.9 \mathrm{~m}$ ) or $\sim 5 \%$ o higher (at 70.8 and $72.9 \mathrm{~m}$ ). Predicted $\delta^{18} \mathrm{O}_{\mathrm{NTR}}$ values were also quite sensitive to ${ }^{15} \varepsilon_{\mathrm{DNF}}$ in this interval with values that were $3.8 \%$ (at $27.9 \mathrm{~m}$ ) and $7.2-8.0 \%$ higher (at 70.8 and $72.9 \mathrm{~m}$ ). While we cannot rule out the potential influence of changes in physiological expression of isotope effects, the sensitivity of $\delta^{15} \mathrm{~N}_{\mathrm{NTR}}$ and $\delta^{18} \mathrm{O}_{\mathrm{NTR}}$ to ${ }^{15} \varepsilon_{\mathrm{DNF}}$ at these depths may point to an unresolvable artifact of this model approach. Further work being indicated, incorporation of dual nitrite isotopes could certainly aid in resolving this apparent sensitivity. However, this sensitivity was not observed in the other transitional intervals of $2 \mathrm{~B}, 3 \mathrm{D}$, or $4 \mathrm{~A}$ and conclusions regarding $\delta^{15} \mathrm{~N}_{\mathrm{NTR}}$ and $\delta^{18} \mathrm{O}_{\mathrm{NTR}}$ still appear robust.

Finally, although literature values of ${ }^{15} \varepsilon_{\mathrm{DNF}}$ almost uniformly fall between values of 13 and $30 \%$, values of ${ }^{15} \varepsilon_{\mathrm{DNF}}$ as low as $2-5 \%$ o have been observed occasionally in culture studies (Granger et al., 2008; Wada et al., 1975). While we have no direct evidence that such low values would be relevant in our study, we report the sensitivity of rate estimates and $\delta^{15} \mathrm{~N}_{\mathrm{NTR}}$ and $\delta^{18} \mathrm{O}_{\mathrm{NTR}}$ (Table 1). In short, a prescribed value for ${ }^{15} \varepsilon_{\text {DNF }}$ of $5 \%$ leads to increased estimates of $\delta^{15} \mathrm{~N}_{\mathrm{NTR}}$ and $\delta^{18} \mathrm{O}_{\mathrm{NTR}}$ by an average of 2.3 and $1.4 \%$, respectively (Figs. 5 and 6). These higher estimates of $\delta^{15} \mathrm{~N}_{\mathrm{NTR}}$ would implicitly require a lower contribution of $\mathrm{N}_{2}$ fixation derived nitrogen as argued for above, though not eliminate its role completely, especially in $4 \mathrm{~A}$ where $\delta^{15} \mathrm{~N}_{\mathrm{NTR}}$ values remain between -1 and $+1 \%$ (Fig. 5). While rates of nitrification were less sensitive (somewhat higher in the upper layers of $4 \mathrm{~A}$ ), this very low prescribed value of ${ }^{15} \varepsilon_{\mathrm{DNF}}$ often lead to dramatically increased estimates of denitrification rates - in particular in the upper transitional layers of profiles at $2 \mathrm{~B}$ and $3 \mathrm{D}$ where $\sim 10-20$-fold higher maximum denitrification rates are required to reconcile nitrate concentration and isotope data (Table 1).

\subsubsection{Model-predicted values of ${ }^{18} \varepsilon:^{15} \varepsilon_{\mathrm{DNF}}$ and ${ }^{15} \varepsilon_{\mathrm{DNF}}$}

In the anoxic intervals, estimated values of ${ }^{18} \varepsilon:{ }^{15} \varepsilon_{\mathrm{DNF}}$ ranged from 0.83 to 1.11 with an average value of $0.99 \pm 0.1$ (Table 2), consistent with a prominent role of respiratory nitrate reductase (Nar), which imparts a ${ }^{18} \varepsilon:{ }^{15} \varepsilon_{\text {DNF }}$ of $\sim 0.96 \pm 0.01$ (Granger et al., 2008). Notably, however, the lower values of 0.86 and 0.83 observed near the top and the core of the anoxic zone in site 2B could suggest influence of nitrate reduction by periplasmic nitrate reductase (Nap) (Granger et al., 2008) and chemolithotrophic $\mathrm{NO}_{3}^{-}$reduction (Frey et al., 2014; Wenk et al., 2014), which has been shown to impart a lower ${ }^{18} \varepsilon:{ }^{15} \varepsilon_{\mathrm{DNF}}$ closer to 0.6 . In this particular interval, this could suggest that as much as $43 \%$ of nitrate reduction is chemolithotrophic and perhaps metabolically linked to the oxidation of inorganic substrates such as reduced iron or sulfur species. Although outside the scope of this study, interrogation of genetic markers of respiratory and periplasmic nitrate reductase could shed more light on the role nitrate use by subsurface microbial communities.

As discussed above, the model-estimated values of ${ }^{15} \varepsilon_{\mathrm{DNF}}$ (averaging $20.0 \% \pm \pm 1.8 \%$; Table 2 ) at site $2 \mathrm{~B}$ are quite consistent with values from a wide range of studies (Granger et al., 2008), and references therein). Notably however, a different pattern emerges from the two anoxic intervals of site 4A. Although model-estimated values of ${ }^{15} \varepsilon_{\text {DNF }}$ were unresolvable at $38.8 \mathrm{~m}$ (likely because the changes in $\delta^{15} \mathrm{~N}$ and $\delta^{18} \mathrm{O}$ were too small for reliable model fits), estimated ${ }^{15} \varepsilon_{\text {DNF }}$ values at $44.1 \mathrm{~m}$ were $\sim 8.1 \pm 0.4 \%$, much lower than observed in 2B. In general, the values observed in $2 \mathrm{~B}$ are consistent with observations from other environments hosting denitrification (Granger et al., 2008), and suggest that denitrifying organisms may be adapted to low levels of carbon (here $<0.2 \%$ sediment organic carbon) and that their physiological poise may be similar to those found in other anaerobic environments (albeit adapted to grow at exceedingly slow nitrate reduction rates). However, the lower estimated ${ }^{15} \varepsilon_{\mathrm{DNF}}$ values in $4 \mathrm{~A}$ might also reflect something else. Given the apparent low reactivity of the sediments of site $4 \mathrm{~A}$, it is also possible that these particularly low ${ }^{15} \varepsilon_{\mathrm{DNF}}$ values stem from denitrification operating under extreme physiological energy limitation - as discussed below.

While a number of studies have shown that the apparent $\mathrm{N}$ isotopic effect for nitrate reduction by denitrification can vary from 5 to 30\%o (e.g., Barford et al., 1999; Delwiche and Steyn, 1970; Granger et al., 2008), recent evidence suggests these variations are largely regulated by changes in the combination of cellular uptake and efflux of $\mathrm{NO}_{3}^{-}$leading to the expression (or repression) of the enzyme-level isotope effect outside the cell (Granger et al., 2008; Kritee et al., 2012; Needoba et al., 2004). For example, at low extracellular $\mathrm{NO}_{3}^{-}$concentrations - low ${ }^{15} \varepsilon_{\mathrm{DNF}}$ values suggest that nitrate transport (having a low ${ }^{15} \varepsilon$ ) becomes the rate-limiting step (Granger et al., 2008; Lehmann et al., 2007; Shearer et al., 1991). In North Pond porewaters, however, at depths where $\mathrm{O}_{2}$ is low enough for denitrification to occur, $\mathrm{NO}_{3}^{-}$ concentrations remain well above $30 \mu \mathrm{M}$, a threshold well above the $K_{\mathrm{m}}$ for $\mathrm{NO}_{3}^{-}$transporters $(2-18 \mu \mathrm{M}$; Parsonage et al., 1985; Murray et al., 1989; Zumft, 1997), suggesting that low ${ }^{15} \varepsilon_{\mathrm{DNF}}$ due to transport limitation of $\mathrm{NO}_{3}^{-}$reduction is unlikely. 
In general, greater expression of the intrinsic enzymatic isotope effect (e.g., higher observed ${ }^{15} \varepsilon_{\mathrm{DNF}}$ ) should occur under conditions in which there is a higher efflux of intracellular $\mathrm{NO}_{3}^{-}$relative to $\mathrm{NO}_{3}^{-}$uptake (Kritee et al., 2012). Interestingly, this efflux/uptake ratio appears to be linked to nitrate reduction rates in denitrifying bacteria, with lower cellspecific nitrate reduction rates leading to lower efflux/uptake ratios and lower observed cellular level ${ }^{15} \varepsilon_{\mathrm{DNF}}$ (Kritee et al., 2012). Indeed, evidence seems to indicate that this efflux/uptake ratio in denitrifying bacteria is highly regulated and that $\mathrm{NO}_{3}^{-}$uptake is sensitive to cellular-level energy supply. For example, under conditions in which organisms are required to maintain a careful regulation of energetically costly metabolic processes, it is logical that there would be a lower density of $\mathrm{NO}_{3}^{-}$transporters and that intracellular $\mathrm{NO}_{3}^{-}$concentrations would be maintained at or near-optimal levels for reduction by nitrate reductase. Similarly, growth under energy-poor carbon substrate supply may also lead to lower observed ${ }^{15} \varepsilon_{\mathrm{DNF}}$, due to an energy-driven decrease in $\mathrm{NO}_{3}^{-}$uptake, lower intracellular $\mathrm{NO}_{3}^{-}$concentrations and a lower efflux/uptake ratio.

We suggest that the difference between the lower ${ }^{15} \varepsilon_{\mathrm{DNF}}$ value estimated from the anoxic interval of $4 \mathrm{~A}$ and the more conventional values from deeper within anoxic intervals of $2 \mathrm{~B}$ could stem from physiological-level controls on the cellular-level expression of ${ }^{15} \varepsilon_{\mathrm{DNF}}$. Specifically, as all porewater evidence from site $4 \mathrm{~A}\left(\mathrm{O}_{2}, \mathrm{NO}_{3}^{-}, \mathrm{N}\right.$ and $\mathrm{O}$ isotopes) indicates substantially lower levels of microbial activity, denitrification may actually be more energy-limited by carbon (compared to denitrification in the deeper intervals of 2B). This suggests that the operation of denitrification under extremely carbon-poor environments (4A) may lead to conditions where the enzyme-level $\mathrm{N}$ isotope fractionation of denitrification is under-expressed on both the cellular, and ecosystem levels, and ${ }^{15} \varepsilon_{\mathrm{DNF}}$ values are much lower than commonly encountered under even just slightly more energyreplete conditions (e.g., 2B).

\section{Summary}

In summary, the porewater nitrate isotopic composition reflects the active redox cycling of nitrogen by the subsurface microbial community - including both oxidative and reductive transformations. The variations in reaction rates across and within the three North Pond sites are generally consistent with the distribution of dissolved oxygen, but not necessarily with the canonical view of how redox thresholds act to spatially separate nitrate regeneration from dissimilatory consumption (e.g., denitrification). The incorporation of nitrate dual isotopes into an inverse reaction-diffusion model provides evidence for extensive zones of overlap where $\mathrm{O}_{2}$ and $\mathrm{NO}_{3}^{-}$respiration (nitrification and denitrification) co-occur. The isotope modeling also yielded estimates for the $\delta^{15} \mathrm{~N}$ and $\delta^{18} \mathrm{O}$ of newly produced nitrate $\left(\delta^{15} \mathrm{~N}_{\mathrm{NTR}}\right.$ and $\left.\delta^{18} \mathrm{O}_{\mathrm{NTR}}\right)$, as well as the isotope effect for denitrification $\left({ }^{15} \varepsilon_{\mathrm{DNF}}\right)$, parameters with high relevance to global ocean models of $\mathrm{N}$ cycling (Sigman et al., 2009). Estimated values of $\delta^{15} \mathrm{~N}_{\mathrm{NTR}}$ were generally lower than previously reported $\delta^{15} \mathrm{~N}$ values for sinking particulate organic matter in this region, suggesting the potential influence of sedimentary $\mathrm{N}_{2}$ fixation and remineralization/oxidation of the newly fixed organic N. Modelestimated values of $\delta^{18} \mathrm{O}_{\mathrm{NTR}}$ generally ranged between -2.8 and $0.0 \%$, consistent with lab studies of nitrifying bacteria cultures. Notably, however, some $\delta^{18} \mathrm{O}_{\mathrm{NTR}}$ values were elevated, suggesting incorporation of ${ }^{18} \mathrm{O}$-enriched dissolved oxygen during the nitrification process, and implying relatively rapid rates of nitrite turnover in environments supporting nitrification. In contrast, the accumulation of $\mathrm{NO}_{2}^{-}$under denitrifying conditions likely reflects limitation of $\mathrm{NO}_{2}^{-}$ reduction by organic matter availability and generally low rates of N-based heterotrophic respiration. Importantly, our findings indicate that the production of organic matter by in situ autotrophy (e.g., nitrification and nitrogen fixation) must supply a substantial fraction of the biomass and organic substrate for heterotrophy in these sediments, supplementing the small organic-matter pool derived from the overlying euphotic zone. Thus, despite exceedingly low exogenous organic matter input, this work sheds new light on an active nitrogen cycle in the deep sedimentary biosphere underlying half of the global ocean.

Author contributions. S. D. Wankel, W. Ziebis, C. B. Wenk, and M. F. Lehmann conceived of the study. S. D. Wankel and W. Ziebis procured funding to carry out the presented work. C. B. Wenk and W. Ziebis participated in the IODP Expedition 336 as shore-based scientists, received and analyzed samples. S. D. Wankel collected samples from frozen archives. S. D. Wankel analyzed the samples, developed the model, and interpreted the model results with assistance from C. Buchwald and M. F. Lehmann. S. D. Wankel wrote the paper with input from C. Buchwald, W. Ziebis, C. B. Wenk, and M. F. Lehmann. All authors discussed the paper and commented on the final manuscript.

Acknowledgements. The authors would like to acknowledge the entire shipboard party of the IODP Expedition 336 for their unflagging efforts during the drilling and collection of these North Pond sediment profiles. We would also like to thank Mark Rollog and Zoe Sandwith for assistance with the isotope and concentration measurements at University of Basel and at WHOI, respectively. SW thanks David Glover for stimulating conversations about model formulations. Funding for this work was provided in part by the International Ocean Drilling Program, Woods Hole Oceanographic Institution and a grant from the Center for Dark Energy Biosphere Investigations (C-DEBI) to $\mathrm{SW}$ and $\mathrm{WZ}$ and a postdoc fellowship to $\mathrm{CB}$ from C-DEBI. WZ was supported in part by NSF grant OCE-1131671. This is C-DEBI contribution number 295.

Edited by: S. Bouillon 


\section{References}

Altabet, M. A.: Variations in nitrogen isotopic compostion between sinking and suspended particles: Implications for nitrogen cycling and particle transformations in the open ocean, Deep-Sea Re. Pt. I, 35, 535-554, 1988.

Altabet, M. A.: A time-series study of the vertical structure of nitrogen and particle dynamics in the Sargasso Sea, Limnol. Oceanogr., 34, 1185-1201, 1989.

Altabet, M. A., Pilskaln, C., Thunell, R. C., Pride, C., Sigman, D. M., Chavez, F. P., and Francois, R.: The nitrogen isotope biogeochemistry of sinking particles from the margin of the Eastern North Pacific, Deep-Sea Res. Pt. I, 46, 655-679, 1999.

Andersson, K. K. and Hooper, A. B.: $\mathrm{O}_{2}$ and $\mathrm{H}_{2} \mathrm{O}$ are each the source of one $\mathrm{O}$ in $\mathrm{NO}_{2}$ produced from $\mathrm{NH}_{3}$ by Nitrosomonas: ${ }^{15}$ N-NMR evidence, FEBS Lett., 164, 236-240, 1983.

Barford, C. C., Montoya, J. P., Atlabet, M. A., and Mitchell, R.: Steady-state Nitrogen Isotope Effects of $\mathrm{N}_{2}$ and $\mathrm{N}_{2} \mathrm{O}$ Production in Paracoccus denitrificans, Appl. Environ. Microb., 65, 989994, 1999.

Becker, K., Langseth, M., and Hyndman, R.: Temperature measurements in Hole 395A, Leg 78B, Washington DC, 689-698, 1984.

Becker, K., Bartetzko, A., and Davis, E. E.: Leg 174B Synopsis: Revisiting Hole 395A for Logging and Long-term Monitoring of Off-axis Hydrothermal Processes in Young Ocean Crust, Proceedings of the Ocean Drilling Program, Scientific Results, 1-13, 2001.

Bender, M. L.: The $\ddot{a}^{18} \mathrm{O}$ of dissolved $\mathrm{O}_{2}$ in seawater: A unique tracer of circulation and respirationin the deep sea, J. Geophys. Res., 95, 22243-22252, 1990.

Berelson, W. M., Hammond, D. E., O’Neill, D., Xu, X.-M., Chin, C., and Zukin, J.: Benthic fluxes and pore water studies from sediments of the central equatorial north Pacific: Nutrient diagenesis, Geochim. Cosmochim. Ac., 54, 3001-3012, 1990.

Bertics, V. J., Sohm, J. A., Treude, T., Chow, C.-E., Capone, D. G., Fuhrman, J. A., and Ziebis, W.: Burrowing deeper into benthic nitrogen cycling: The impact of bioturbation on nitrogen fixation coupled to sulfate reduction, Mar. Ecol.-Prog. Ser., 409, 1-15, 2010.

Blair, N. E. and Aller, R. C.: The fate of terrestrial organic carbon in the marine environment, Annual Review of Marine Science, 4, 401-423, doi:10.1146/annurev-marine-120709-142717, 2012.

Bothe, H., Schmitz, O., Yates, M. G., and Newton, W. E.: Nitrogen fixation and hydrogen metabolism in cyanobacteria, Microbiol. Mol. Biol. R., 74, 529-551, 2010.

Bourbonnais, A., Lehmann, M. F., Waniek, J. J., and Schulz-Bull, D. E.: Nitrate isotope anomalies reflect $\mathrm{N}_{2}$ fixation in the Azores Front region (subtropical NE Atlantic), J. Geophys. Res., 114, C03003, doi:10.1029/2007JC004617, 2009.

Braman, R. S. and Hendrix, S. A.: Nanogram nitrite and nitrate determination in environmental and biological materials by vanadium (III) reduction with chemiluminescence detection, Anal. Chem., 61, 2715-2718, 1989.

Brewer, P. G., Hofmann, A. F., Peltzer, E. T., and Ussler III, W.: Evaluating microbial chemical choices: The ocean chemistry basis for the competition between use of $\mathrm{O}_{2}$ or $\mathrm{NO}_{3}^{-}$as an electron acceptor, Deep-Sea Res. Pt. I, 87, 35-42, 2014.

Buchwald, C. and Casciotti, K. L.: Oxygen isotopic fractionation and exchange during bacterial nitrite oxidation, Limnol. Oceanogr., 55, 1064-1074, 2010.
Buchwald, C. and Casciotti, K. L.: Isotopic ratios of nitrite as tracers of the sources and age of oceanic nitrite, Nat. Geosci., 6, 309313, 2013.

Buchwald, C., Santoro, A. E., McIlvin, M. R., and Casciotti, K. L.: Oxygen isotopic composition of nitrate and nitrite produced by nitrifying cocultures and natural marine assemblages, Limnol. Oceanogr., 57, 1361-1375, doi:10.4319/lo.2012.57.5.1361, 2012.

Capone, D. G., Burns, J. A., Montoya, J. P., Subramaniam, A., Mahaffey, C., Gunderson, T., Michaels, A. F., and Carpenter, E. J.: Nitrogen fixation by Trichodesmium spp.: An important source of new nitrogen to the tropical and subtropical North Atlantic Ocean, Global Biogeochem. Cy., 19, GB2024, doi:10.1029/2004GB002331, 2005.

Casciotti, K. L. and McIlvin, M. R.: Isotopic analyses of nitrate and nitrite from reference mixtures and application to Eastern Tropical North Pacific waters, Mar. Chem., 107, 184-201, 2007.

Casciotti, K. L., Sigman, D. M., Galanter-Hastings, M., Böhlke, J. K., and Hilkert, A.: Measurement of the oxygen isotopic composition of nitrate in seawater and freshwater using the denitrifier method, Anal. Chem., 74, 4905-4912, 2002.

Casciotti, K. L., Trull, T. W., Glover, D., and Davies, D.: Constraints on nitrogen cycling at the subtropical North Pacific Station ALOHA from isotopic measurements of nitrate and particulate nitrogen, Deep-Sea Res. Pt. II, 55, 1661-1672, 2008.

Casciotti, K. L., McIlvin, M., and Buchwald, C.: Oxygen isotopic exchange and fractionation during bacterial ammonia oxidation, Limnol. Oceanogr., 55, 753-762, 2010.

Christensen, J. P. and Rowe, G. T.: Nitrification and oxygen consumption in northwest Atlantic deep-sea sediments, J. Mar. Res., 42, 1099-1116, 1984.

Christensen, J. P., Murray, J. W., Devol, A. H., and Codispoti, L. A.: Denitrification in continental shelf sediments has major impact on the ocean nitrogen budget, Global Biogeochem. Cy., 1, 97116, 1987.

Clark, I. and Fritz, P.: Environmental Isotopes in Hydrogeology, CRC Press, Boca Raton, Florida, 331 pp., 1997.

Cox, R. D.: Determination of nitrate and nitrite at the parts per billion level by chemiluminescence, Anal. Chem., 52, 332-335, 1980.

Davis, E. E., Becker, K., Pettigrew, T., Carson, B., and MacDonald, R.: CORK: A Hydrological Seal and Downhole Observatory for Deep-Ocean Boreholes, 139, 43-53, 1992.

Defforey, D. and Paytan, A.: Data Report: Characterisitics of sedimentary phosphorus at North Pond, IODP Expedition 336, Tokyo, Japan, 2015.

Delwiche, C., Zinke, P., Johnson, C., and Virginia, R.: Nitrogen isotope distribution as a presumptive indicator of nitrogen fixation, Bot. Gaz., 140, 65-69, 1979.

Delwiche, C. C. and Steyn, P. L.: Nitrogen isotope fractionation in soils and microbial reactions, Environ. Sci. Technol., 4, 929-935, 1970.

Devol, A. H.: Direct measurement of nitrogen gas fluxes from continental shelf sediments, Nature, 349, 319-321, 1991.

D’Hondt, S., Spivack, A. J., Pockalny, R., Ferdelman, T. G., Fischer, J. P., Kallmeyer, J., Abrams, L. J., Smith, D. C., Graham, D., Hasiuk, F., Schrum, H., and Stancin, A. M.: Subseaflor sedimentary life in the South Pacific Gyre, P. Natl. Acad. Sci. USA, 106, 11651-11656, 2009. 
D’Hondt, S., Inagaki, F., Zarikian, C. A., Abrams, L. J., Dubois, N., Engelhardt, T., Evans, H., Ferdelman, T., Gribsholt, B., Harris, R. N., Hoppie, B. W., Hyun, J.-H., Kallmeyer, J., Kim, J., Lynch, J. E., McKinley, C. C., Mitsunobu, S., Morono, Y., Murray, R. W., Pockalny, R., Sauvage, J., Shimono, T., Shiraishi, F., Smith, D. C., Smith-Duque, C. E., Spivack, A. J., Steinsbu, B. O., Suzuki, Y., Szpak, M., Toffin, L., Uramoto, G., Yamaguchi, Y. T., Zhang, G.-1., Zhang, X.-H., and Ziebis, W.: Presence of oxygen and aerobic communities from sea floor to basement in deep-sea sediments, Nat. Geosci., 8, 299-303, 2015.

Edwards, K. J., Wheat, C. G., and Sylvan, J. B.: Under the Sea: Microbial Life in Volcanic Oceanic Crust, Nature Reviews in Microbiology, 9, 703-712, 2011.

Edwards, K. J., Bach, W., Klaus, A., and Scientists, E.: Mid-Atlantic Ridge microbiology: Initiation of long-term coupld microbiological, geochemical, and hydrological experimentation within the seafloor at North Pond, western flank of the Mid-Atlantic Ridge, Integrated Ocean Drilling Program Management International, Inc., Tokyo, Japan, 2012a.

Edwards, K. J., Becker, K., and Colwell, F.: The deep, dark energy biosphere: Intraterrestrial life on Earth, Annu. Rev. Earth Pl. Sc., 40, 551-568, doi:10.1146/annurev-earth-042711-105500, 2012b.

Estep, M. L. F. and Macko, S. A.: Nitrogen isotope biogeochemistry of thermal springs, Org. Geochem., 6, 779-785, 1984.

Expedition 336 Scientists: Mid-Atlantic Ridge microbiology: Initiation of long-term coupled microbiological, geochemical and hydrological experimentation within the seafloor at North pond, western flank of the Mid-Atlantic Ridge, IODP, Preliminary Report for Expedition 336, doi:10.2204/iodp.pr.336.2012, 2012.

Fawcett, S. E., Ward, B. B., Lomas, M. W., and Sigman, D. M.: Vertical decoupling of nitrate assimilation and nitrification in the Sargasso Sea, Deep-Sea Res. Pt. I, 103, 64-72, 2015.

Fischer, J. P., Ferdelman, T. G., D'Hondt, S., Røy, H., and Wenzhöfer, F.: Oxygen penetration deep into the sediment of the South Pacific gyre, Biogeosciences, 6, 1467-1478, doi:10.5194/bg-6-1467-2009, 2009.

Frey, C., Heitanen, S., Jürgens, K., Labrenz, M., and Voss, M.: $\mathrm{N}$ and $\mathrm{O}$ isotope fractionation in nitrate during chemolithoautotrophic denitrification by Sulfurimonas gotlandica, Environ. Sci. Technol., 48, 13229-13327, doi:10.1021/es503456g, 2014.

Gable, R., Morin, R., and Becker, K.: Geothermal state of DSDP Holes 333A, 395A and 534A: Results from the DIANAUT program, Geophys. Res. Lett., 19, 505-508, 1992.

Garside, C.: A chemiluminscent technique for the determination of nanomolar concentrations of nitrate and nitrite in seawater, Mar. Chem., 11, 159-167, 1982.

Goloway, F. and Bender, M. L.: Diagenetic models of interstitial nitrate profiles in deep sea suboxic sediments, Limnol. Oceanogr., 27, 624-638, 1982.

Granger, J., Sigman, D. M., Needoba, J. A., and Harrison, P. J.: Coupled nitrogen and oxygen isotope fractionation of nitrate during assimilation by cultures of marine phytoplankton, Limnol. Oceanogr., 49, 1763-1773, 2004.

Granger, J., Sigman, D. M., Lehmann, M. F., and Tortell, P. D.: Nitrogen and oxygen isotope fractionation during dissimilatory nitrate reduction by denitrifying bacteria, Limnol. Oceanogr., 53, 2533-2545, 2008.
Granger, J. and Sigman, D. M.: Removal of nitrite with sulfamic acid for nitrate $\mathrm{N}$ and $\mathrm{O}$ isotope analysis with the denitrifier method, Rapid Commun. Mass Sp., 23, 3753-3762, 2009.

Granger, J., Sigman, D. M., Rohde, M., Maldonado, M., and Tortell, P. D.: $\mathrm{N}$ and $\mathrm{O}$ isotope effects during nitrate assimilation by unicellular prokaryotic and eukaryotic plankton cultures, Geochim. Cosmochim. Ac., 74, 1030-1040, 2010.

Granger, J., Prokopenko, M. G., Sigman, D. M., Mordy, C. W., Morse, Z. M., Morales, L., Sambrotto, R. N., and Plessen, B.: Coupled nitrification-denitrification in sediment of the eastern Bering Sea shelf leads to ${ }^{15} \mathrm{~N}$ enrichment of fixed $\mathrm{N}$ in shelf waters, J. Geophys. Res., 116, C11006, doi:10.1029/2010JC006751, 2011.

Grasshoff, K., Kremling, K., and Ehrhardt, M.: Methods of Seawater Analysis, 3 Edn., Wiley, Weinheim, Germany, 1999.

Gruber, N.: The Marine Nitrogen Cycle Overview and Challenges, in: Nitrogen in the Marine Environment, 2nd Edn., edited by: Capone, D. G., Bronk, D. A., Mulholland, M. R., and Carpenter, E. J., Elsevier, Amsterdam, the Netherlands, 1-50, 2008.

Grundmanis, V. and Murray, J. W.: Aerobic respiration of pelagic marine sediments, Geochim. Cosmochim. Ac., 46, 1101-1120, 1982.

Hammond, D. E., McManus, J., Berelson, W. M., Kilgore, T. E., and Pope, R. H.: Early diagenesis of organic material in equatorial Pacific sediments: stoichiometry and kinetics, Deep-Sea Res. Pt. II, 43, 1365-1412, 1996.

Hoch, M. P., Fogel, M. F., and Kirchman, D. L.: Isotope fractionation associated with ammonium uptake by a marine bacterium, Limnol. Oceanogr., 37, 1447-1459, 1992.

Holmes, R., Aminot, A., Kerouel, R., Hooker, B., and Peterson, B. J.: A simple and precise method for measuring ammonium in marine and freshwater ecosystems, Can. J. Fish Aquat. Sci., 56, 1801-1808, 1999.

Jahnke, R. A., Emerson, S. R., and Murray, J. W.: A model of oxygen reduction, denitrification, and organic matter mineralization in marine sediments, Limnol. Oceanogr., 27, 610-623, 1982.

Joye, S. B. and Paerl, H. W.: Contemporaneous nitrogen fixation and denitrificaiton in intertidal microbial mats - rapid response to runoff events, Mar. Ecol.-Prog. Ser., 94, 267-274, 1993.

Karsh, K. L., Granger, J., Kritee, K., and Sigman, D. M.: Eukaryotic assimilatory nitrate reductase fractionates $\mathrm{N}$ and $\mathrm{O}$ isotopes with a ratio near unity, Environ. Sci. Technol., 46, 5727-5735, doi:10.1021/es204593q, 2012.

Knapp, A. N.: The sensitivity of marine $\mathrm{N}_{2}$ fixation to dissolved inorganic nitrogen, Frontiers in Microbiology, 3, 374, doi:10.3389/fmicb.2012.00374, 2012.

Knapp, A. N., Sigman, D. M., and Lipschultz, F.: N isotopic composition of dissolved organic nitrogen and nitrate at the Bermuda Atlantic Time-series Study site, Global Biogeochem. Cy., 19, GB1018, doi:10.1029/2004GB002320, 2005.

Kritee, K., Sigman, D. M., Granger, J., Ward, B. B., Jayakumar, A., and Deutsch, C.: Reduced isotope fractionation by denitrificaiton under conditions relevant to the ocean, Geochim. Cosmochim. Ac., 92, 243-259, 2012.

Kroopnick, P. and Craig, H.: Oxygen isotope fractionation in dissolved oxygen in the deep sea, Earth Planet. Sc. Lett., 32, 375388, 1976. 
Kroopnick, P., Weiss, R. F., and Craig, H.: Total $\mathrm{CO}_{2},{ }^{13} \mathrm{C}$, and dissolved oxygen ${ }^{18} \mathrm{O}$ at GEOSECS II in the North Atlantic, Earth Planet. Sc. Lett., 16, 103-110, 1972.

Langseth, M. G., Becker, K., von Herzen, R. P., and Schultheiss, P.: Heat and fluid flux through sediment on the western flank of the Mid-Atlantic Ridge: A hydrogeological study of North Pond, Geophys. Res. Lett., 19, 517-520, doi:10.1029/92GL00079, 1992.

Lehmann, M. F., Bernasconi, S. M., Barbieri, A., and McKenzie, J. A.: Preservation of organic matter and alteration of its carbon and nitorgen isotope composition during simulated and in situ early sedimentary diagenesis, Geochim. Cosmochim. Ac., 66, 3573$3584,2002$.

Lehmann, M. F., Sigman, D. M., and Berelson, W. M.: Coupling the ${ }^{15} \mathrm{~N} /{ }^{14} \mathrm{~N}$ and ${ }^{18} \mathrm{O} /{ }^{16} \mathrm{O}$ of nitrate as a constraint on benthic nitrogen cycling, Mar. Chem., 88, 1-20, 2004.

Lehmann, M. F., Sigman, D. M., McCorkle, D. C., Brunnelle, B. G., Hoffman, S., Kienast, M., Cane, G., and Clement, J.: Origin of the deep Bering Sea nitrate deficit: Constraints from the nitrogen and oxygen isotopic composition of water column nitrate and benthic nitrate fluxes, Global Biogeochem. Cy., 19, GB4005, doi:10.1029/2005GB002508, 2005.

Lehmann, M. F., Sigman, D. M., McCorkle, D. C., Granger, J., Hoffman, S., Cane, G., and Brunelle, B. G.: The distribution of nitrate $15 \mathrm{~N} / 14 \mathrm{~N}$ in marine sediments and the impact of benthic nitrogen loss on the isotopic composition of oceanic nitrate, Geochim. Cosmochim. Ac., 71, 5384-5404, 2007.

Lehmann, M. F., Barnett, B., Gelinas, Y., Gilbert, D., Maranger, R. J., Mucci, A., Sundby, B., and Thibodeau, B.: Aerobic respiration and hypoxia in the Lower St. Lawrence Estuary: Stable isotope ratios of dissolved oxygen constrain oxygen sink partitioning, Limnol. Oceanogr., 54, 2157-2169, 2009.

Li, Y.-H. and Gregory, S.: Diffusion of ions in sea water and in deepsea sediments, Geochim. Cosmochim. Ac., 38, 703-714, 1974.

Marconi, D., Weigand, M. A., Rafter, P. A., McIlvin, M. R., Forbes, M., Casciotti, K. L., and Sigman, D. M.: Nitrate isotope distributions on the US GEOTRACES North Atlantic cross-basin section: Signals of polar nitrate sources and low latitude nitrogen cycling, Mar. Chem., 177, 143-156, 2015.

Mason, O. U., Nakagawa, T., Rosner, M., van Nostrand, J. D., Zhou, J., Maruyama, A., Fisk, M. R., and Giovannoni, S. J.: First investigation of the microbiology of the deepest layer of ocean crust, PLoS One, 5, e15399, doi:10.1371/journal.pone.0015399, 2010.

McIlvin, M. and Casciotti, K. L.: Technical updates to the bacterial method for nitrate isotopic analyses, Anal. Chem., 83, 18501856, 2011.

McIlvin, M. R. and Casciotti, K. L.: Fully automated system for stable isotopic analyses of dissolved nitrous oxide at natural abundance levels, Limnol. Oceanogr.-Meth., 8, 54-66, 2010.

McManus, J., Hammond, D. E., Berelson, W. M., Kilgore, T. E., Demaster, D. J., Ragueneau, O. G., and Collier, R. W.: Early diagenesis of biogenic opal: Dissolution rates, kinetics, and paleoceanographic implications, Deep-Sea Res. Pt. II, 42, 871-903, 1995.

Meador, T. B., Aluwihare, L. I., and Mahaffey, C.: Isotopic heterogeneity and cycling of organic nitrogen in the oligotrophic ocean, Limnol. Oceanogr., 52, 934-947, 2007.
Minigawa, M. and Wada, E.: Nitrogen isotope ratios of red tide organisms in the East China Sea: A characterization of biological nitrogen fixation, Mar. Chem., 19, 245-259, 1986.

Montoya, J. P., Holl, C. M., Zehr, J. P., Hansen, A., Villareal, T. A., and Capone, D. G.: High rates of $\mathrm{N}_{2}$ fixation by unicellular diazotrophs in the oligotrophic Pacific ocean, Nature, 430, 10271032, doi:10.1038/nature02824, 2004.

Mosier, A. C. and Francis, C. A.: Relative abundance and diversity of ammonia-oxidizing archaea and bacteria in the San Francisco Bay estuary, Environ. Microbiol., 10, 3002-3016, doi:10.1111/j.1462-2920.2008.01764.x, 2008.

Murray, R., Parsons, L., and Smith, M.: Kinetics of nitrate utilization by mixed populations of denitrifying bacteria, Appl. Environ. Microb., 55, 717-721, 1989.

Murray, J. W. and Grundmanis, V.: Oxygen consumption in pelagic marine sediments, Science, 209, 1527-1530, 1980.

Nakagawa, S., Takai, K., Inagaki, F., Horikoshi, K., and Sako, Y.: Nitratiruptor tergarcus gen. no., sp. nov. and Nitratifractor salsuginis gen. nov., sp. nov., nitrate-reducing chemolithoautotrophs of the å-Proteobacteria isolated from a deep-sea hydrothermal system in the Mid-Okinawa Trough, Int. J. Syst. Evol. Micr., 55, 925-933, 2005.

Needoba, J. A., Sigman, D. M., and Harrison, P. J.: The mechanism of isotope fractionation during algal nitrate assimilation as illuminated by the $15 \mathrm{~N} / 14 \mathrm{~N}$ of intracellular nitrate, J. Phycol., 40, 517-522, 2004.

Nunoura, T., Nishizawa, M., Kikuchi, T., Tsubouchi, T., Hirai, M., Koide, O., Miyazaki, J., Hirayama, H., Koba, K., and Takai, K.: Molecular biological and isotopic biogeochemical prognoses of the nitrification-driven dynamic microbial nitrogen cycle in hadopelagic sediments, Environ. Microbiol., 15, 3087-3107, doi:10.1111/1462-2920.12152, 2013.

Orcutt, B. N., Sylvan, J. B., Knab, N. J., and Edwards, K. J.: Microbial Ecology of the Dark Ocean above, at, and below the Seafloor, Microbiol. Mol. Biol. Rev., 75, 361-422, 2011.

Orcutt, B. N., Wheat, C. G., Rouxel, O., Hulme, S., Edwards, K. J., and Bach, W.: Oxygen consumption in subseafloor basaltic crust, Nature, 4, 2539, doi:10.1038/ncomms3539, 2013.

Parsonage, D., Greenfield, A. J., and Ferguson, S. J.: The high affinity of Paracoccus denitrificans cells for nitrate as an electron acceptor, Analysis of possible mechanisms of nitrate and nitrite movement across the plasma membrane and the basis for inhibition by added nitrite of oxidase activity in permeabilised cells, Biochim. Biophys. Acta, 807, 81-95, 1985.

Picard, A. and Ferdelman, T.: Linking microbial heterotrophic activity and sediment lithology in oxic, oligotrophic sub-seafloor sediments of the North Atlantic Ocean, Frontiers in Microbiology, 2, 263, doi:10.3389/fmicb.2011.00263, 2011.

Prokopenko, M. G., Hirst, M., DeBrabandere, L., Lawrence, D., Berelson, W. M., Granger, J., Chang, B., Dawson, S. C., Crane III, E., Chong, L., Thamdrup, B., Townsend-Small, A., and Sigman, D. M.: Nitrogen losses in anoxic marine sediments driven by Thioploca-anammox bacteria consortia, Nature, 500, 194 198, doi:10.1038/nature12365, 2013.

Rabalais, N. N.: Nitrogen in Aquatic Environments, Ambio, 31, 102-112, 2002.

Rao, A. M. and Charette, M. A.: Benthic nitrogen fixation in a eutrohpic estuary affected by groundwater discharge, J. Coastal Res., 28, 477-485, 2012. 
Ren, H., Sigman, D. M., Thunell, R. C., and Prokopenko, M. G.: Nitrogen isotopic composition of planktonic foraminifera from the modern ocean and recent sediments, Limnol. Oceanogr., 57, 1011-1024, 2012.

Risgaard-Petersen, N.: Coupled nitrification-denitrification in autotrophic and heterotrophic estuarine sediments: On the influence of benthic microalgae, Limnol. Oceanogr., 48, 93-105, 2003.

Røy, H., Kallmeyer, J., Adhikari, R. R., Pockalny, R., Jorgensen, B. B., and D'Hondt, S.: Aerobic microbial respiration in 86million-year-old deep-sea red clay, Science, 336, 9220-925, doi:10.1126/science.1219424, 2012.

Rutgers van der Loeff, M., Meadows, P., and Allen, J.: Oxygen in porewaters of deep-sea sediments [and Discussion], Philos. T. R. Soc. B, 331, 69-84, 1990.

Rysgaard, S., Risgaard-Petersen, N., Nielsen, L. P., and Revsbech, N. P.: Nitrification and Denitrification in Lake and Estuarine Sediments Measured by the ${ }^{15} \mathrm{~N}$ Dilution Technique and Isotope Pairing, Appl. Environ. Microb., 59, 2093-2098, 1993.

Sachs, O., Sauter, E., Schlüter, M., Rutgers van der Loeff, M. M., Jerosch, K., and Holby, O.: Benthic organic carbon flux and oxygen penetration reflect different plankton provinces in the Southern Ocean, Deep-Sea Res. Pt. I, 56, 1319-1335, 2009.

Seeberg-Elverfeldt, J., Schlüter, M., Feseker, T., and Kölling, M.: Rhizon sampling of porewaters near the sediment-water interface of aquatic systems, Limnol. Oceanogr.-Meth., 3, 361-371, 2005.

Seitzinger, S. P., Nixon, S. W., and Pilson, M. E. Q.: Denitrification and nitrous oxide production in a coastal marine ecosystem, Limnol. Oceanogr., 29, 73-83, 1984.

Shearer, G. B., Schneider, J. D., and Kohl, D. H.: Separating the efflux and influx components of net nitrate uptake by Synechococcus R2 under steady-state conditions, J. Gen. Microbiol., 137, 1179-1184, 1991.

Sigman, D. M., Casciotti, K. L., Andreani, M., Barford, C., Galanter, M., and Böhlke, J. K.: A Bacterial Method for the Nitrogen Isotopic Analysis of Nitrate in Seawater and Freshwater, Anal. Chem., 73, 4145-4153, 2001.

Sigman, D. M., Granger, J., DiFiore, P. J., Lehmann, M. F., Ho, R., Cane, G., and van Geen, A.: Coupled nitrogen and oxygen isotope measurements of nitrate along the eastern North Pacific margin, Global Biogeochem. Cy., 19, GB4022, doi:10.1029/2005GB002458, 2005.

Sigman, D. M., DiFiore, P. J., Hain, M., Deutsch, C., Wang, Y., Karl, D. M., Knapp, A. N., Lehmann, M. F., and Pantoja, S.: The dual isotopes of deep nitrate as a constraint on the cycle and budget of oceanic fixed nitrogen, Deep-Sea Rea. Pt. I, 56, 1419-1439, doi:10.1016/j.dsr.2009.04.007, 2009.
Usui, T., Koike, I., and Ogura, N.: $\mathrm{N}_{2} \mathrm{O}$ Production, Nitrification and Denitrification in an Estuarine Sediment, Estuarine Coastal Shelf Sci., 52, 769-781, 2001.

Wada, E., Kadonaga, T., and Matsuo, S.: $15 \mathrm{~N}$ abundance in nitrogen of naturally occurring substances and global assessment of denitrification from isotopic viewpoint, Geochem. J., 9, 139-148, 1975.

Wankel, S. D., Kendall, C., Pennington, J. T., Chavez, F. P., and Paytan, A.: Nitrification in the euphotic zone as evidenced by nitrate dual isotopic composition: Observations from Monterey Bay, California, Global Biogeochem. Cy., 21, GB2009, doi:10.1029/2006gb002723, 2007.

Wankel, S. D., Kendall, C., and Paytan, A.: Using nitrate dual isotopic composition $\left(\ddot{a}^{15} \mathrm{~N}\right.$ and $\left.\ddot{a}^{18} \mathrm{O}\right)$ as a tool for exploring sources and cycling of nitrate in an estuarine system: Elkhorn Slough, California, J. Geophys. Res., 114, G01011, doi:10.1029/2008JG000729, 2009.

Wankel, S. D., Mosier, A. C., Hansel, C. M., Paytan, A., and Francis, C. A.: Spatial variability in nitrification rates and ammonium oxidizing microbial communities in the agriculturally impacted Elkhorn Slough estuary, California, Appl. Environ. Microb., 77, 269-280, 2011.

Wenk, C. B., Zopfi, J., Blees, J., Veronesi, M., Niemann, H., and Lehmann, M. F.: Community $\mathrm{N}$ and $\mathrm{O}$ isotope fractionation by sulfide-dependent denitrificaiton and anammox in a stratified lacustrine water column, Geochim. Cosmochim. Ac., 125, 551563, doi:10.1016/j.gca.2013.10.034, 2014.

Zhang, X., Sigman, D. M., Morel, F. M. M., and Kraepiel, A. M. L.: Nitrogen isotope fractionation by alternative nitrogenases and past ocean anoxia, P. Natl. Acad. Sci. USA, 111, 4782-4787, 2014.

Zhao, R. and Jørgensen, S. L.: Microbial nitrogen cycling in oligotrophic sediments from the Mid Atlantic Ridge, ISME J., in review, 2015.

Ziebis, W., McManus, J., Ferdelman, T., Schmidt-Schierhorn, F., Bach, W., Muratli, J., Edwards, K. J., and Villinger, H.: Interstitial fluid chemistry of sediments underlying the North Atlantic Gyre and the influence of subsurface fluid flow, Earth Planet. Sc. Lett., 323-324, 79-91, 2012.

Zumft, W. G.: Cell biology and molecular basis of denitrification, Microbiol. Mol. Biol. R., 61, 533-616, 1997. 